\title{
Country Transparency and the Global Transmission of Financial Shocks
}

Luis Brandao-Marques, Gaston Gelos, and Natalia Melgar 


\title{
IMF Working Paper
}

Institute for Capacity Development

\section{Country Transparency and the Global Transmission of Financial Shocks \\ Prepared by Luis Brandao-Marques, Gaston Gelos, and Natalia Melgar*}

$\mathrm{Ju} Q 2013$

\section{This Working Paper should not be reported as representing the views of the IMF.} The views expressed in this Working Paper are those of the author(s) and do not necessarily represent those of the IMF or IMF policy. Working Papers describe research in progress by the author(s) and are published to elicit comments and to further debate.

\begin{abstract}
This paper considers the role of country-level opacity (the lack of availability of information) in amplifying shocks emanating from financial centers. We provide a simple model where, in the presence of ambiguity (uncertainty about the probability distribution of returns), prices in emerging markets react more strongly to signals from the developed market, the more opaque the emerging market is. The second contribution is empirical evidence for bond and equity markets in line with this prediction. Increasing the availability of information about public policies, improving accounting standards, and enhancing legal frameworks can help reduce the unpleasant side effects of financial globalization.

JEL Classification Numbers: G12, G15

Keywords: transparency, emerging markets, transmission of global financial shocks Author's E-Mail Address: 1marques@imf.org,ggelos@imf.org, nmelgar@imf.org

\footnotetext{
* We thank Laura Jaramillo for sharing her data and Joscha Beckmann, Marcos Chamon, Reda Cherif, Stijn Claessens, Juan-Carlos Hatchondo, Ian Hinsdale, Yi Huang, Sebnem Kalemli-Ozcan, Iryna Kaminska, Nicolás Magud, Camelia Minoiu, Jorge Roldós, Skander Van Den Heuvel, Richard Walton, and Anke Weber for comments, as well as participants at seminars at the IMF and Joint Vienna Institute, and at the Infiniti 2013 conference.
} 
I. Introduction

II. Model

III. Empirical Strategy and Variables ........................................................................10

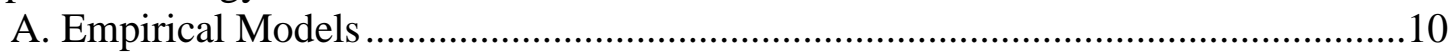

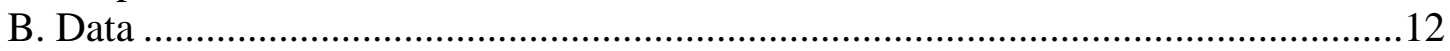

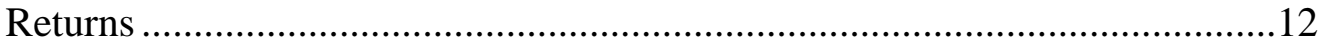

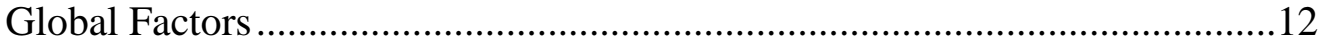

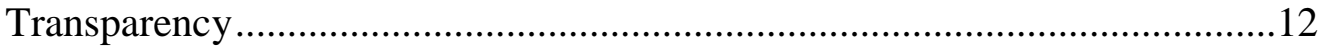

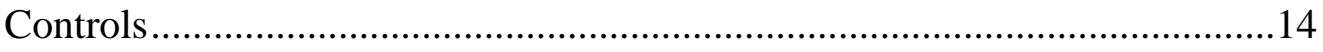

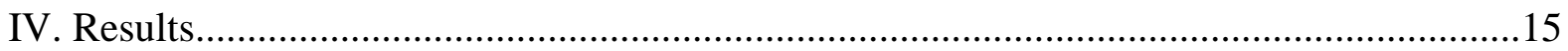

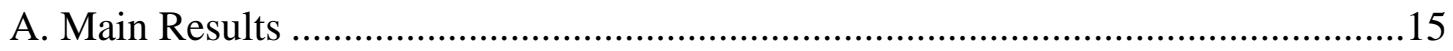

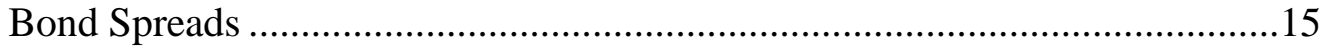

Equity Returns ……………………….................................................15

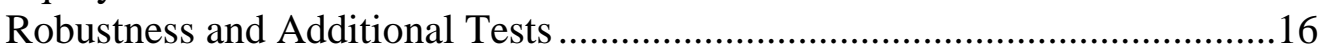

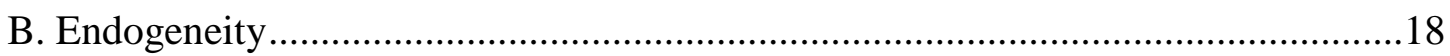

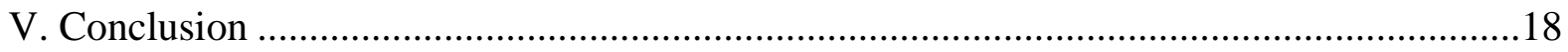

Appendix A - Model Details and Proofs ............................................................................20

Appendix B - List of Countries Used in the Sample ............................................................23

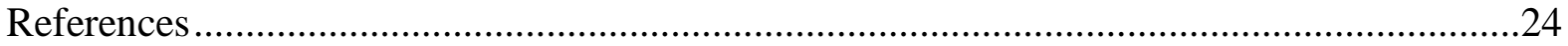

\section{TABLES}

Table 1 - Correlations between Measures of Opacity, Risk, and Liquidity..............................29

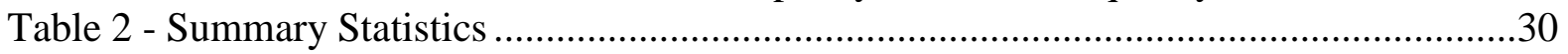

Table 3 - Global Shocks, Bond Returns and Transparency: Linear Effects .............................31

Table 4 - Global Shocks, Bond Returns and Transparency: Asymmetric Effects ....................32

Table 5 - Global Shocks, Stock Returns and Transparency: Linear Effects............................33

Table 6 - Global Shocks, Stock Returns, and Transparency: Asymmetric Effects ...................34

Table 7 - Global Shocks, Stock Returns, Transparency, and Country Risk Ratings .................35

Table 8 - Global Shocks, Stock Returns, Transparency, and Market Liquidity ……................36

Table 9 - Granger Causality between Opacity and Volatility ..................................................37

\section{FIGURES}

Figure 1 - Change in Bond Spreads during Global Financial Crisis (Sept-Dec 2008) ..............4

Figure 2 - Change in Stock Prices during Global Financial Crisis (Sept-Dec 2008) .................4 


\section{INTRODUCTION}

It has frequently been asserted that increasing transparency at the country level (defined as the availability and reliability of information about a country's public and private sectors) can be beneficial both in attracting investment while helping to avoid excessive capital flow volatility (see, for example, Goldstein, 1998, IMF 2001, Frenkel and Menkhoff, 2004, and Gai, 2003). The argument is that more transparency enhances the orderly and efficient functioning of financial markets, reducing the occurrence of phenomena such as herding, waves of sentiment-driven flows, and excessive investor reactions to news.

Recent events seem to support this idea. The drop in equity prices and the increase in bond spreads in emerging markets during the most acute phase of the 2007-2009 financial crisis (fourth quarter of 2008) was sharpest for countries with higher levels of opacity (Figures 1 and 2). More generally, the global financial crisis has drawn renewed attention to episodes of flight-to-quality and the role of opacity in the financial system in exacerbating shocks (see Brunnermeier and Pedersen, 2009, Caballero and Krishnamurthy, 2008, and Claessens, 2009, to name a few).

On the other hand, Furman, Stiglitz, Bosworth, and Radelet (1998), Morris and Shin (2002), and Morris, Shin, and Tong (2006) argue that more transparency can actually be destabilizing, because it may yield excessive provision of information, possibly crowding out private information, reducing information efficiency, and increasing volatility. Empirically, the evidence remains ambiguous. ${ }^{1}$

\footnotetext{
${ }^{1}$ There is some evidence that more transparency reduces the volatility of capital flows. Gelos and Wei (2005) report that during crises, funds tend to retreat more from less transparent countries. Gande and Parsley (2006) find that less corrupt countries are less vulnerable to downgrades by rating agencies, when vulnerability is measured by mutual fund outflows. Köhler (2006) finds that countries with a higher dispersion of macroeconomic forecasts experience more sudden stops. Johnson, and others (2000) report that countries with better governance suffered less during the Asian crisis. Wei and Yu (2002) find evidence that poor public governance is associated with a higher loan-to-FDI ratio, a composition of capital flows associated with a higher incidence of currency crises. On the other hand, Tong (2007), analyzing stock market analysts' forecasts for thirty developing countries, reports that the impact of transparency initiatives is limited because public disclosure crowds out private investments in information.
} 
Figure 1 - Change in Bond Spreads during Global Financial Crisis (Sept-Dec 2008)

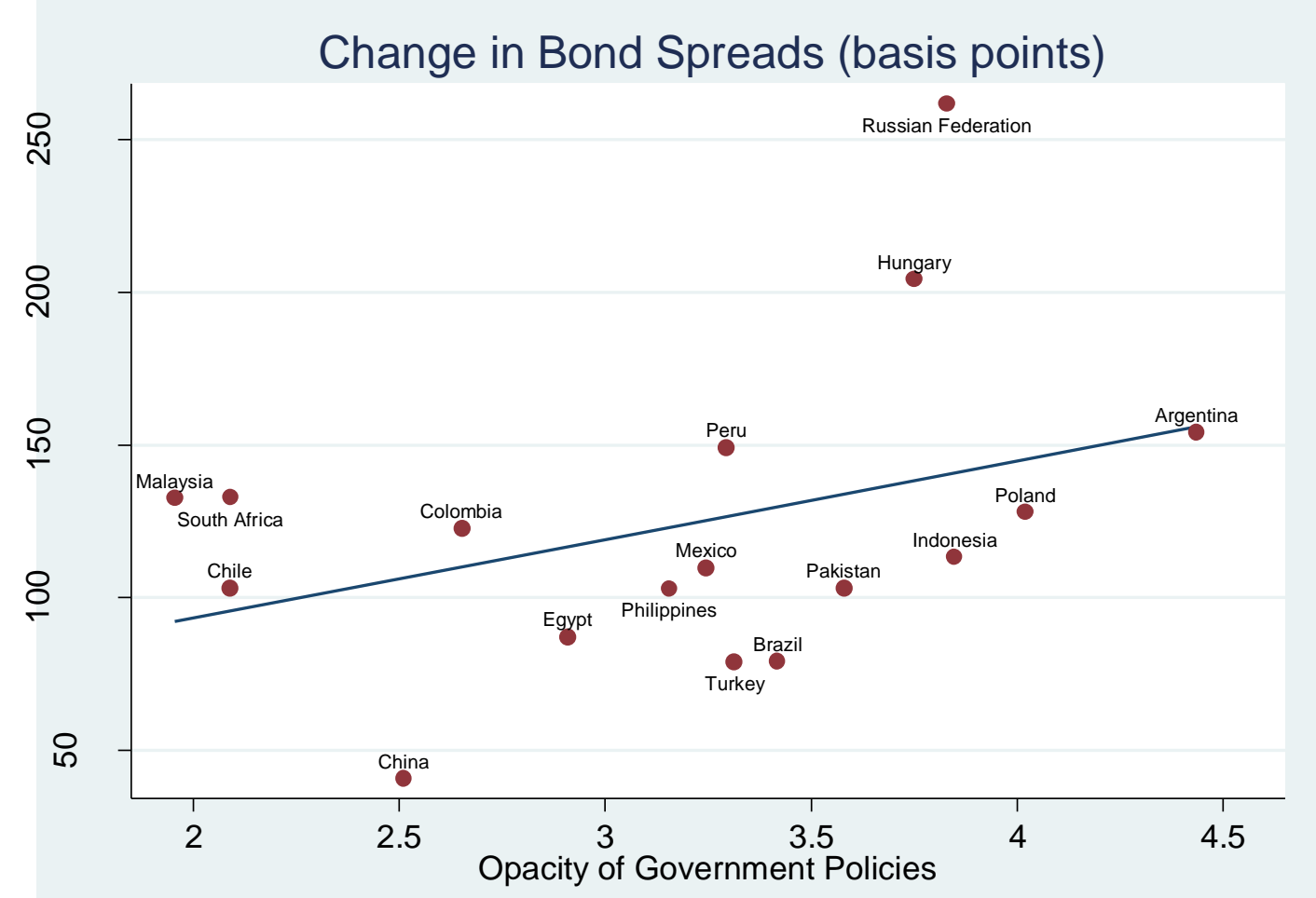

Figure 2 - Change in Stock Prices during Global Financial Crisis (Sept-Dec 2008)

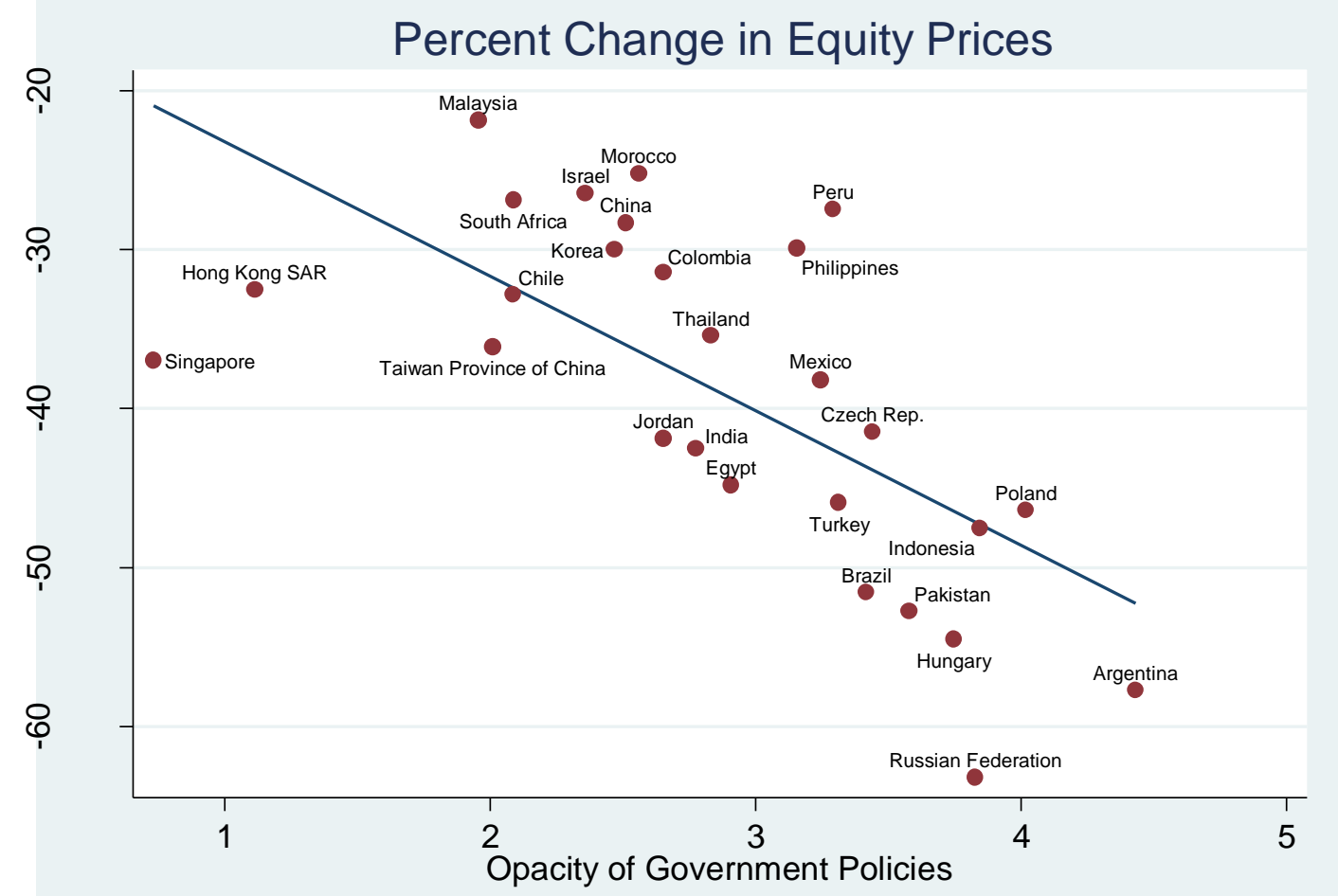


In parallel, a substantial body of literature has been examining the role of disclosure at the firm level in influencing the cost of capital, stock return volatility, and liquidity. This research suggests that, among other things, transparency can enhance a stock's liquidity (see for example, Amihud, Mendelson and Pedersen, 2005, and Lang, Lins, and Maffett, 2012) and reduce liquidity volatility (Lang and Maffet, 2011). More generally, there is evidence linking better governance with lower stock price volatility (Claessens and Yurtoglu, 2012). ${ }^{2}$

However, little systematic research has so far been devoted to the role of country-level transparency in shaping the international transmission of financial shocks - a gap we aim to start filling with this study. We examine how opacity at the country level can amplify the local impact of changes in global market conditions, examining the performance of emerging financial markets in response to shocks emanating from the financial centers. The basic hypothesis is the following. When global financial conditions are benign, international investors become more prone to invest in markets whose underlying distribution of risks they understand less well ("ambiguous" markets). This could happen for various reasons. One is that investors might become more comfortable with ambiguity when their other investments have performed well (analogous to a reduction in risk aversion in response to positive wealth shocks). Alternatively, it could be the outcome in a setting in which during difficult times, fund managers face more scrutiny and more pressure to justify the asset composition of their portfolios, reducing their exposure to assets whose risks are less well understood.

Consequently, they will be more prone to hold more opaque assets during "good" times than during "bad times." As a result, more opaque markets experience larger booms when financial market conditions are favorable, while the opposite is true during bad times. Alternatively, ambiguity may makes it harder for investors to separate fundamental shocks from pure noise shocks, inducing them to associate benign signals in the financial centers with good fundamentals in the ambiguous markets.

We develop an intuition along the latter lines in a simple model with Knightian uncertainty (uncertainty about the underlying probability distribution of returns. Investors are based in a financial center (whose distribution of returns they know) but also invest in a class of assets (emerging markets) that displays varying degrees of opacity. In this stylized framework, we show that prices of more opaque assets react more strongly to shocks in the financial center. ${ }^{3}$ In essence, ambiguity in fundamentals leads investors to behave as if emerging markets were

\footnotetext{
${ }^{2}$ The literature on firm-level effects suggests that the effects of transparency may not be unambiguously positive either. Easley and O'Hara (2009) argue that increasing disclosure requirements can increase the risk premium when investors face ambiguity since it increases the awareness of very bad outcomes and reduces market participation.

${ }^{3}$ Drees, Eckwert, and Vardy (2013) develop a very different model with somewhat related predictions. In their setting, when interest rates are high, investors choose transparent projects with high fundamental risk; but when interest rates are low, they choose opaque projects that are fundamentally safe. Hong and Sraer (2012) provide a model in which high-beta assets are more prone to speculative overpricing than low beta ones since they are more sensitive to disagreements about the common factor of cash flows.
} 
riskier than what they actually are and interpret any signal as more likely to reflect a fundamental shock. An interesting feature of the model is that the overreaction to developed market shocks in opaque markets is not due to noisier signals from these markets but rather related to incomplete information or ambiguity about risks and returns. Therefore, our simple setup helps to illustrate how different dimensions of "transparency" can have different implications for asset price volatility.

Our main contribution is, however, empirical. Using data for both stock and bond markets over the period 1997-2011, we consistently find that emerging markets that score worse on various dimensions of opacity (ranging from the degree of corporate disclosure and transparency of government policies to broader measures of opacity such as corruption perceptions) react more strongly to global market conditions (measured by the VIX) than those that are more transparent. Importantly, this result holds even when controlling for a broad range of measures of risk, credit quality, and liquidity. ${ }^{4}$ This mechanism — which so far has not been stressed in the literature on financial contagion-may therefore help explain the patterns of financial shock transmission across countries. ${ }^{5}$

The results imply that emerging markets are not helpless vis-à-vis the ups and downs of global markets. Countries wishing to benefit from financial globalization can reduce its unpleasant side effects by becoming more transparent - that is, by providing more and more timely data, improving corporate disclosure standards, and more generally by improving governance.

\section{MODEL}

In this section we present a simple model with uncertainty about the distribution of risks (ambiguity) and ambiguity aversion to provide a clear conceptual framework for our empirical analysis and derive testable hypotheses. In essence, ambiguity aversion implies that agents prefer known risks to unknown risks. We start with a pure exchange economy with a representative agent with preferences displaying smooth ambiguity aversion (see Klibanoff, Marinacci, and Mukerji, 2005), in a setting similar to Caskey's (2009).

There are two risky assets and a risk-free asset which earns zero interest and acts as numeraire. Investors receive one informative signal per asset and then trade. After trading, each risky asset (assets 1 and 2) pays a final dividend $\left(d_{1}\right.$ and $\left.d_{2}\right)$ and the agent consumes all his/her wealth. The supply of the risky assets is exogenously given by $\boldsymbol{y}=\left[\begin{array}{ll}y_{1} & y_{2}\end{array}\right]^{\prime}$.

\footnotetext{
${ }^{4}$ A separate issue from the one we analyze here is whether transparency affects country risk assessments as measured by sovereign spreads (Cady and Pelecchio, 2008, Glennerster and Shin, 2008) and ratings (Arbatli and Escolano, 2012). There is compelling evidence suggesting a beneficial effect of fiscal transparency on both measures. In addition, Arbatli, Hashimoto and Wacker (2012), and Gelos and Wei (2005) find a positive impact of transparency on foreign direct investment and mutual fund portfolio holdings, respectively.

${ }^{5}$ Information differentials play a role in some contagion models such as Calvo and Mendoza (2000) and Kodres and Pritsker (2002). See Forbes (2012) for a recent discussion of the contagion literature.
} 
The agent has a CARA utility function defined over final wealth $u(w)=-A^{-1} \exp (-A w)$ and constant relative ambiguity aversion preferences given by $h(E(u(w)))=-a^{-1}(-E(u(w)))^{a}$ (Gollier, 2011), where A describes the degree of absolute risk aversion and $a \geq 1$ the degree of ambiguity aversion ( $a=1$ means ambiguity-neutrality or Savage preferences).

The information structure is one of ambiguity in fundamentals, where investors are familiar with interpreting information but lack expertise to appropriately value the first asset (the emerging market asset), at least relatively to the second asset (the developed asset). Ambiguity in fundamentals (as opposed to ambiguity in information) aims at representing a situation where market participants are able to process the information provided to them (such as company annual reports or country macroeconomic analysis papers) but lack specific background knowledge about the economy, sector, or firm at hand to interpret it properly. For instance, in this setting, investors lack information about an emerging country's institutions, governance, or policies. In the empirical sections of this paper, Sections III and IV, we link this failure to understand the data generating processes of asset returns from emerging markets to country-level opacity.

Our agent receives one noisy signal for each asset, which can be decomposed into a fundamental (the dividend) and noise or a non fundamental shock. We assume that while the fundamentals can be correlated across markets, the noise shocks are not. Therefore, the agent receives the following signals:

$$
\begin{aligned}
& s_{1}=d_{1}+\varepsilon_{1} \\
& s_{2}=d_{2}+\varepsilon_{2}
\end{aligned}
$$

where both noise terms, $\varepsilon_{1}$ and $\varepsilon_{2}$, are unambiguous and normal i.i.d., with mean zero and variance $\sigma_{\varepsilon 1}^{2}$ and $\sigma_{\varepsilon 2}^{2}$.

The dividend of asset 2 is known to be normal, with known mean $\mu_{2}$ and variance $\sigma_{2}^{2}$, which implies $E\left(s_{2}\right)=\mu_{2}$ and $\operatorname{var}\left(s_{2}\right)=\sigma_{2}^{2}+\sigma_{\varepsilon 2}^{2}$. The dividend for asset 1 is ambiguous, with mean $\mu_{1}+b$, where $b$ is unknown but for which the agent has prior beliefs given by $b \sim N\left(\mu_{b}, \sigma_{b}{ }^{2}\right)$. This means we have $d_{1}=u_{1}+b$ where $u_{1} \sim N\left(\mu_{1}, \sigma_{u 1}{ }^{2}\right)$ and $\operatorname{var}\left(d_{1}\right)=\sigma_{u 1}{ }^{2}+\sigma_{b}{ }^{2} \equiv \tilde{\sigma}_{1}^{2}$, as in Caskey (2009). Therefore, we can decompose the unconditional variance of the dividend for asset 1 in two parts. The first part reflects the true fundamental volatility of this asset $\left(\sigma_{u 1}^{2}\right)$ and the second part, the ambiguity surrounding asset returns in the emerging market as given by the variance of prior beliefs $\left(\sigma_{b}^{2}\right)$.

Solving the optimization problem for this consumer, given the joint and conditional distributions of signal and dividend processes derived in Appendix A, we obtain the following expression for the optimal asset allocation:

$$
\theta^{*}=\frac{1}{A}(\operatorname{var}(d \mid s)+(a-1)(\operatorname{var}(d \mid s)-\operatorname{var}(d \mid J)))^{-1}(E(d \mid s)-p),
$$


where $\boldsymbol{p}=\left[\begin{array}{ll}p_{1} & p_{2}\end{array}\right]^{\prime}$ is the vector of prices for the two assets.

The market equilibrium condition gives us the price vector $\boldsymbol{p}^{*}$ such that $\boldsymbol{\theta}^{*}=\boldsymbol{y}$. By replacing $\boldsymbol{y}$ for $\boldsymbol{\theta}^{*}$ in (1) we can easily derive it to be:

$$
p^{*}=E(d \mid s)-A(\operatorname{var}(d \mid s)+(a-1)(\operatorname{var}(d \mid s)-\operatorname{var}(d \mid J))) y .
$$

After some algebra, we can show that the variance matrices in (2) do not depend on $s_{1}$ or $s_{2}$ and that the only way through which prices depend directly on the signals is through $E(d \mid s)$. Therefore, in this setting, the sensitivity of prices to signals does not depend on the degree of ambiguity aversion. ${ }^{6}$ Without loss of generality, we can set $\mathrm{a}=1$ (ambiguity-neutrality) for the remainder of the section.

In what follows, we use comparative statics to show two key properties of the model. First, that if information in the emerging market is noisier, asset prices in this market react less to signals coming from the developed market. Second, if there is more ambiguity about the emerging market's fundamentals, asset prices in this market react more to signals coming from the developed market.

We have the following propositions.

Proposition 1: If the fundamentals in the two markets are positively correlated $(\rho>0)$, the sensitivity of the price of asset 1 (emerging market) to a shock in the developed market (signal 2) is decreasing in the variance of the non fundamental shock to asset 1 . This means, $\frac{\partial^{2} p_{1}}{\partial s_{2} \partial \sigma_{\varepsilon 1}^{2}}<0$.

\section{Proof.}

See Appendix A.

The previous claim establishes that noisier information (or signals) in the emerging market leads to this market being less, not more, sensitive to shocks in the developed market. To understand the intuition, suppose there were no ambiguity. Agents know that the fundamentals in the two markets are positively correlated but they also know that the signals they get are noisy. Suppose agents receive a positive signal from the developed market, which, although unknown to them, stems from a positive shock to fundamentals in that market. Since earnings in the two markets are positively correlated, fundamentals in the emerging market also improve. This translates into a positive signal from the emerging market. If signals from this market are very noisy, agents will assign a lower probability to

\footnotetext{
${ }^{6}$ The model can be easily expanded to include heterogeneity with respect to the degree of aversion to ambiguity but with homogeneous information. In this setting, one can show that the sensitivity of prices to signals does not depend on the fraction of ambiguity-averse versus ambiguity-neutral investors either. The results are available from the authors upon request.
} 
the possibility that the signal reflects improvements in fundamentals, so they tend not to believe that earnings are increasing in the emerging market as well. Therefore, when public information in emerging markets is very noisy, prices in those markets will react less to a signal coming from developed markets. ${ }^{7}$ This means that, within our model, any overreaction to developed market shocks in more opaque emerging markets cannot be due to noisier information in these markets but rather related to incomplete information or ambiguity.

We are therefore interested in showing that the sensitivity of the price of asset 1 (emerging market) to a shock in the developed market (signal 2) is increasing in ambiguity (measured by the variance of the prior belief about $b$ ). That is,

$$
\frac{\partial^{2} p_{1}}{\partial s_{2} \partial \sigma_{b}^{2}}=\frac{\partial^{2} p_{1}}{\partial s_{2} \partial \sigma_{1}} \frac{\partial \sigma_{1}}{\partial \sigma_{b}^{2}}>0
$$

This happens as long as emerging market prices respond positively (negatively) to good (bad) news in the developed market, i.e., $\partial p_{1} / \partial s_{2}>0$ and for non degenerate noise terms $\varepsilon_{1}$ and $\varepsilon_{2}$. We show this in the following proposition derived from the model.

Proposition 2 The sensitivity of the price of asset 1 (emerging market) to a shock in the developed market (signal 2) is increasing in ambiguity (measured by the variance of the prior belief about $b$ ) as long as $\rho>0$.

\section{Proof:}

See Appendix A.

The intuition for this result is as follows. An increase in ambiguity is represented by an increase in the variance of the subjective prior belief for $b$. This translates into an increase in the unconditional variance of the emerging market fundamental, $\mathrm{d}_{1} \cdot{ }^{8}$ Other things equal, this raises the signal-to-noise ratio in the emerging market. Since the two signals $\left(\mathrm{s}_{1}\right.$ and $\left.\mathrm{s}_{2}\right)$ are correlated via the fundamentals, a positive (negative) signal in the developed market will tend to coincide with a positive (negative) signal in the emerging market. As the perceived signal-to-noise ratio increases with the level of ambiguity in the emerging market, prices will react more. Therefore, the introduction of ambiguity in fundamentals leads investors to behave as if emerging markets were riskier than what they actually are and to associate with a higher probability a given signal to a fundamental shock. This in turn leads to higher price sensitivity to market signals. Proposition 2 is the testable implication of our model.

\footnotetext{
${ }^{7}$ In fact, they react less to any signal, regardless of where it originates.

${ }^{8}$ As mentioned before, the unconditional variance of the fundamental $d_{l}$ is the sum of its conditional (relative to the ambiguous component $b$ ) variance and the variance of the prior belief for $b$.
} 


\section{EMPIRICAL STRATEgY AND VARIABLES}

\section{A. Empirical Models}

Our aim is to estimate the impact of a global signal (the $s$ in our model) on bond and stock returns in emerging markets. Specifically, we want to test whether economic and financial opacity, measured at the country level, affects the transmission of global shocks to local market returns. We are aware that many decisions concerning the disclosure of information relevant to assess assets' risks and returns are taken at the firm level. However, our focus on country-level effects and measures is supported by the existing literature on the greater importance of country-level institutions when determining firm-level governance quality (Doidge, Karolyi, and Stulz, 2007).

In light of the predominant role attributed in the literature to the VIX (a measure of the market volatility implicit in U.S. stock options) as a proxy for liquidity conditions and risk aversion in financial centers (see for example Fratzscher, 2012), we focus on this variable as our main global factor. ${ }^{9}$

To capture the differential effect of opacity on the transmission of global shocks, we interact changes in the VIX with various measures of country-level opacity (see description below) in specifications for stock and bond returns with standard controls. We use data at a weekly frequency. ${ }^{10}$ To distinguish the role of opacity from credit quality and other risks, we also include interactions of VIX changes with proxies for these factors. To account for the trend increase in global market integration over the past 20 years (see Bekaert, Harvey, Lundblad, and Siegel, 2011), we also include interactions with a time trend. ${ }^{11}$ Lastly, to control for other common shocks, we include year dummies.

Following the empirical literature on emerging market bond spreads, our baseline specification for bonds is as follows:

$$
\Delta r_{i t}^{b}=\alpha_{i}+\left(\beta_{1}+\beta_{2} \times t\right) \Delta f_{t}+\beta_{3} \text { Opacity }_{i t}+\beta_{4} \text { Opacity }_{i t} \times \Delta f_{t}+\gamma^{\prime} \mathbf{x}_{i t-1}^{b}+\sum_{j=1}^{M} \delta Y E A R_{j t}+\varepsilon_{i t},
$$

where $r^{b}$ is a sovereign bond index return, $f$ is a global risk factor, $t$ is a time trend, $\mathbf{x}^{b}$ is a vector of lagged controls, and $\operatorname{YEARj}(\mathrm{j}=1, \ldots, \mathrm{M})$ is a set of year dummies. We choose to model the change in spreads rather than the level because, for our sample period and for most countries, spreads exhibited a considerable amount of persistence or even a seemingly non

\footnotetext{
${ }^{9}$ The VIX is in fact a measure for the risk-neutral expected variance of global asset returns (see Bollerslev, Tauchen, and Zhou, 2009).

${ }^{10}$ We also used daily data (with somewhat fewer controls), obtaining very similar results to the ones reported below. These are available from the authors upon request.

${ }^{11}$ Opacity itself can be regarded as a market barrier which prevents full integration (see Stulz, 1981, Errunza and Losq, 1985, Bekaert and Harvey, 1995, and Stulz, 1999). This potentially complicates the analysis of equity returns.
} 
stationary behavior. ${ }^{12}$ We include as controls the weekly change in the United States' threemonth T-bill rate, the on-the-run-off-the-run spread as a measure of global market liquidity, the percentage change in the exchange rate against the U.S. dollar, a series of dummies to capture periods of banking, currency, and debt crises, as well as a measure of country sovereign risk. ${ }^{13}$ We also control for bond market restrictions by including a dummy which takes value one if there are measures in place which restrict the ability of foreign investors to buy bonds or equities.

Our specification for equities is:

$$
r_{i t}^{e}=\alpha_{i}+\left(\beta_{1 w}+\beta_{2 w} \times t\right) r_{t}^{w}+\left(\beta_{1}+\beta_{2} \times t\right) \Delta f_{t}+\beta_{3} \text { Opacity }_{i t}+\beta_{4} \text { Opacity }_{i t} \times \Delta f_{t}+\gamma^{\prime} \mathbf{x}_{i t-1}^{e}+\varepsilon_{i t},
$$

where $r^{e}$ is an equity index excess return (equity price index return in excess of the U.S. 3month T-bill rate), $r^{w}$ is the world excess return, and $\mathbf{x}^{e}$ is a vector of lagged controls. ${ }^{14}$

In addition to the U.S. market's excess stock return (as a proxy for the world market), we include the lagged dividend yield for the country as a measure of the expected excess return and to possibly capture information about future earnings and future interest rates (see Ang and Bekaert, 2007 and Bekaert, Ehrman, Fratzcher, and Mehl, 2011). As we did for bonds, we include dummies for financial crises, and a dummy variable for restrictions on purchases of equities by foreigners in the domestic market. We also include weekly currency returns against the U.S. dollar as a local control because exchange rate risk may be priced (see Dumas and Solnik, 1995). We are, however, not interested in testing a particular asset pricing model and include currency returns to control for a conditional (on world equity returns and other factors) or residual country-wide exposure to currency risk (Bodnar and Wong, 2003 and Dominguez and Tesar, 2006).

We also condition on the degree of market integration. ${ }^{15}$ Specifically, we follow Bekaert, Ehrman, Fratzcher, and Mehl (2011) and use both trade openness and capital openness measures. These measures of market segmentation (one based on international trade and the other on capital flows) are then interacted with the global factor. ${ }^{16}$

\footnotetext{
${ }^{12}$ This is probably due to regime switches and to the low power of unit root tests in this type of setting.

${ }^{13}$ See Comelli (2012), González-Rosada and Levy Yeyati (2008), Jaramillo and Tejada (2011), and Hartelius, Kashiwase, and Kodres (2008), among others.

${ }^{14}$ Our empirical model exclusively relies on factors based on public information (which is consistent with our model from Section II). However, Albuquerque, Bauer, and Schneider (2009) show that global private information is an important explanation of equity returns and cross-border trades. Combining global private information with country-level transparency would be an important extension of our work.

${ }^{15}$ See Bekaert, Harvey, and Ng, 2005 for a discussion of the importance of accounting for market integration/segmentation when studying the transmission of global financial shocks. In fact, our empirical model can be seen as a reduced form of their factor model approach. See also Fratzscher and Imbs (2009) for a discussion of the role of financial openness and institutions in attracting capital flows.

${ }^{16}$ In addition to proxying for economic and financial integration, trade is in itself an important determinant of cross-country linkages between financial centers and peripheral markets (Forbes and Chinn, 2004).
} 
For all regressions, report Driscoll-Kraay standard errors, which are robust to very general forms of spatial and temporal dependence as the time dimension becomes large (Driscoll and Kraay, 1998). This choice is supported by evidence provided by performing Breusch-Pagan's test of cross-sectional independence for each regression (also valid for large $T$ ). Unreported results clearly reject the null of cross-sectional independence at any conceivable significance level (available from the authors upon request).

\section{B. Data}

We collect data for a list of up to twenty-seven emerging countries (see list in Appendix B) starting in January 1997 and ending in December 2011. Next we provide a more detailed description of the variables used and their data sources.

\section{Returns}

For bond spread data, we use changes in the EMBI Global return index. To compute our equity return series, we use the MSCI stock market total return indices. For each country, we calculate weekly and daily returns and then subtract the 3-month T-bill interest rate for the U.S. to calculate excess returns. Using U.S. dollar returns is in line with the flavor of our model, which is based on a global investor. All return data are from DataStream.

\section{Global Factors}

The global factors are captured by changes in the VIX index, which we retrieve from DataStream. ${ }^{17}$ This variable has been used in settings similar to ours to explain equity returns (Bekaert, Ehrman, Fratzcher, and Mehl, 2011), as well as market segmentation and capital flows (Bekaert, Harvey, Lundblad, and Siegel, 2011).

\section{Transparency}

Our description of how transparency may relate to asset prices has focused on "Knightian uncertainty," i.e. the imperfect knowledge of (ambiguity about) the probability distribution of events. We are therefore interested in indices of opacity that measure the availability of all relevant information allowing the investor to assess the probability of risks associated with investing in a given country. This suggests using relatively broad indices capturing the difficulty of assessing true risks for an investor in an economy. We therefore focus on indices measuring corruption, governance, corporate disclosure practices, and accounting standards. Specifically, we employ the following indicators of opacity at the country level:

Opacity Index (Opacit). In 2000, the accountancy and consulting company PricewaterhouseCoopers (PwC) conducted a survey of banks, firms, equity analysts,

\footnotetext{
${ }^{17}$ For equities, we also used the MSCI world return as a global factor without altering the main results (not shown).
} 
and in-country staff in 35 countries to generate measures of opacity in five areas (PricewaterhouseCoopers, 2001): Bureaucratic practices (corruption), the legal system, government macroeconomic policies, accounting standards and practices, and the regulatory regime. PricewaterhouseCoopers aimed at interviewing at least 20 CFOs, five bankers, five equity analysts, and five PricewaterhouseCoopers employees in each country. The scores for the five areas were aggregated to form a single index, the opacity index. Later, the index continued to be produced by the Milken Institute (Kurtzman, Phumiwasana, and Yago, 2004, and Kurtzman and Yago, 2008 and 2009).

Corruption Perceptions (Corrup). As another proxy for opacity, we use the Corruption Perceptions Index computed by Transparency International (see Transparency International, 2001). While corruption is not the same as a lack of opacity in the sense defined earlier, it captures hard-to-quantify risk of investing in a country, and is significantly correlated with measures of opacity (Table 1). It also has the advantage of being available in time-series format for a longer period and a larger number of countries.

Corporate Opacity (Corpop). The annual Global Competitiveness Report produced by the World Economic Forum includes results from surveys about the level of financial disclosure and availability of information about companies. The survey measures the perceptions of over 3,000 executives about the country in which they operate and covers 53 countries. The respondents were asked to assess the validity of the statement "The level of financial disclosure required is extensive and detailed" with a score from 1 (=strongly disagree) to 7 (strongly agree). Based on these results, we construct a summary variable called Corporate Opacity.

Transparency of Government Policies (TGP). This variable has the same source and methodology as the Corporate Opacity indicator. The respondents were asked to assess the validity of the statement "Firms in your country are usually informed clearly and transparently by the government on changes in policies and regulations affecting your industry" with a score from 1 (=never informed) to 7 (always fully and clearly informed). We use as Transparency of Government Policies the mean score per country as reported by the Global Competitiveness Reports from 2002-2003 to $2011-2012 .^{18}$

Wilshire Score $\left(\mathbf{W}_{\text {as }}\right)$. For several years, Wilshire Associates in cooperation with Oxford Analytica calculated on behalf of CalPERS the Wilshire Score Index

\footnotetext{
${ }^{18}$ We use the first year mentioned on each report's title to assign the scores on a yearly basis (i.e. we use data from the 2002-2003 report for 2002). The Global Competitiveness Report 2005-2006 does not report this question. For 2005, we linearly interpolate the values from the 2004-2005 and 2006-2007 reports. See World Economic Forum (various years).
} 
Transparency Factor (Wilshire Associates, various years) to determine permissible equity markets for investment. We use the factor on accounting standards $\left(\mathrm{W}_{\mathrm{as}}\right)$.

Disclosure. This variable is the "disclosure in periodic filings" component of Djankov, and others' (2008) anti-self-dealing index. See Table 1 (item 1.2) of Djankov, and others for details.

ROSC. This indicator is a dummy variable which switches from one to zero once the country first IMF Report on Standards and Codes (covering 12 areas identified as important by the IMF and the World Bank) has been published.

For completeness, we use the same set of opacity variables for both bond and equity regressions. However, some opacity indices (such as corporate opacity or disclosure) should be more relevant for equity returns than for bond returns (where dimensions such as the transparency of government policies and the publication of standards and codes reports should matter more).

\section{Controls}

Our data for the U.S. 3-Month Treasury bills rate, the exchange rate against the U.S. dollar, and the dividend-yield (implicit in MSCI indices) come from DataStream. The on-the-runoff-the-run spread is calculated as in the Chicago Fed's National Financial Conditions Index (NFCI) and is the difference between the series FYCEPA and FCM10 from Haver Analytics. Sovereign risk is measured by the Standard \& Poor's Rating and Outlook Index. The tradebased measure of market segmentation is the average for the previous twelve months of total merchandise trade of each country with the U.S. and comes from the Bureau of Economic Analysis. The capital flows-based measure of segmentation is the sum of purchases and sales of foreign equities to and from U.S. investors by nationals of each country in the previous twelve months, and is from the Treasury International Capital System (TIC) database maintained by the U.S. Treasury. The two measures of capital controls, for bonds and equities, are based on the IMF's Annual Report on Exchange Arrangements and Exchange Restrictions (AREAER) database (1999-2011).

We present, in Table 2, summary statistics for our main variables of interest: asset returns, VIX changes, and opacity indexes. 


\section{RESUlts}

\section{A. Main Results}

\section{Bond Spreads}

The results for bond spreads are generally in line with our hypothesis that price sensitivity is increasing in opacity (Proposition 2). In six of the seven specifications, the interaction of the opacity variable with changes in the VIX is positive and statistically significant. In particular, as expected, the Corruption, Transparency of Government Policies, and ROSC indices significantly amplify the reaction of bond yields to uncertainty shocks (although the interaction with the ROSC variable is only significant at the ten percent level.)

In terms of economic significance, a country in the bottom 10 percentile of transparency (in terms of perceptions of corruption by TI) is expected to experience, over the period of one week, a 1.7 percentage point higher increase in spreads in response to a 10-percentage-point increase in the VIX, compared to a country in the highest 10 percentile.

The signs of the rest of the coefficients are mostly in line with our priors, although not always statistically significant. As expected, the occurrence of banking and debt crises significantly affects bond yields, but currency crisis do not. The interaction of VIX shocks with credit quality - as measured by the S\&P credit ratings - is not significant in all but one case. This suggests that with our transparency measures we are capturing a different dimension beyond mere credit quality. ${ }^{19}$

\section{Equity Returns}

Similarly to the case of bond spreads, stock returns tend to react less strongly to VIX shocks in more transparent emerging markets (Table 5). Most interactions of VIX changes with country opacity are statistically significant at the one percent level (the interactions of VIX changes with the PWC Opacity index and ROSC publication date variable are not significant). This effect is also economically significant since the decline in equity returns induced by a 10 percent increase in the VIX, over the period of one week, is 0.29 percentage points higher for countries in the $90^{\text {th }}$ percentile of Transparency of Government Policies index (i.e. the top 10 percent most opaque countries) than for those on the $10^{\text {th }}$ percentile. This is about double the average weekly change in the MSCI for the countries included in our sample.

\footnotetext{
${ }^{19}$ We also estimated a similar specification with daily data, including day-of-the week dummies, remove the crises dummies, and the lagged dependent variable (to account for time-zone differences in trading days) as controls. The size and significance of the effects are similar to the ones estimated for weekly data. The results (for bond and equity returns) are available from the authors.
} 
As expected, equity markets that are more integrated financially with the rest of the world indeed suffer more from VIX fluctuations. This is evident in the fact that the interaction terms with capital flows are negative and statistically significant. ${ }^{20}$ The interaction of the VIX with trade openness turns out to be insignificant. These two findings are in line with the notion that the transmission of financial shocks to equity markets across the globe happens mostly through the financial channel and not through the trade channel (see Didier, Love, and Martinez-Peria, 2012, for a recent account). Except for the dividend yield and the change in the exchange rate (which enter significantly), the other variables have the expected sign but are not statistically significant.

\section{Robustness and Additional Tests}

Opacity vs. generic country risk. Our results may be affected by the fact that some or all of our opacity measures may be capturing other, more generic country-specific risk; in other words, we may be attributing a special role to opacity whereas in fact the differential reaction we observe is due to some other idiosyncratic, country-level risk. Controlling for such risks is important because, in the model presented in Section II, we cannot distinguish the effect of an increase in ambiguity (increased variance of prior beliefs) from that of an increase in underlying fundamental volatility or risk. This is unlikely to be problematic for the specification with bond returns since we already include a widely used measure of sovereign risk as a control. Therefore, in exploring robustness we focus on equity returns and add to the list of controls a measure of country risk and interact it with the change in the global factor as well. We use the ICRG Composite Country Risk Rating (published by the PRS Group) as a measure of political, economic, and financial country risk. ${ }^{21}$ The inclusion of this additional interaction actually tends to increase the estimated effect of the opacity indices somewhat, while the patterns of statistical significance remain unchanged (Table 7).

Opacity vs. liquidity. An alternative possibility is that measures of opacity are correlated with market liquidity (particularly in the case of equities), and that less liquid emerging markets react more strongly to global signals. In principle, most of the literature suggests causation from transparency to liquidity (see, for example, Lang and Maffet, 2011), which would imply that controlling separately for liquidity in our regressions could result in underestimating the true impact of transparency. Nevertheless, when we include measures of market liquidity (lagged by one period) such as the one proposed by Amihud (2002), in our regressions for equity markets, the interaction terms with illiquidity do not enter significantly. The significance of our opacity variables drops in all but two cases, suggesting a problem of

\footnotetext{
${ }^{20}$ We tried adding to the list of global integration variables the index constructed by Bekaert and others (2011) for effective or de facto equity market segmentation. The results (which can be made available) are very similar to those in Table 5. We thank Geert Bekaert and Stephan Siegel for sharing their data.

${ }^{21}$ A higher Composite Country Risk Rating (CRR) means lower country risk. See Bekaert, and others (2012) for a description of considering political risk in international valuations and of the ICRG political risk indicator.
} 
multicollinearity (Table 9). ${ }^{22}$ Nevertheless, the interaction terms still enter significantly in four out of the seven cases, including for those indices most relevant for equity returns (corporate opacity, disclosure, and accounting standards). ${ }^{23}$

Asymmetric responses. We are also interested in checking whether our results are affected by the nature of the global shock. Specifically, we want to know if the strength with which global financial shocks are amplified into highly opaque countries relative to low-opacity ones is different depending on whether shocks are adverse (increases in VIX) or benign (drops in VIX). This results in a modification to our baseline specifications (3) and (4) as follows:

$$
\begin{aligned}
& \Delta r_{i t}^{b}=\alpha_{i}+\beta_{G 1} \Delta f_{t} I\left(\Delta f_{t}<0\right)+\beta_{B 1} \Delta f_{t} I\left(\Delta f_{t}>0\right)_{t}+\beta_{2} \Delta f_{t} \times t+\beta_{3} \text { Opacity }_{i t}+\beta_{G 4} \text { Opacity }_{i t} \\
& \quad \times \Delta f_{t} I\left(\Delta f_{t}<0\right)+\beta_{B 4} \text { Opacity }_{i t} \times \Delta f_{t} I\left(\Delta f_{t}>0\right)+\gamma^{\prime} \mathbf{x}_{i t-1}^{b}+\sum_{j=1}^{M} \delta Y E A R_{j t}+\varepsilon_{i t},
\end{aligned}
$$

and

$$
\begin{aligned}
r_{i t}^{e}= & \alpha_{i}+\left(b_{1 w}+b_{2 w} \times t\right) r_{i t}^{w}+\beta_{G 1} \Delta f_{t} I\left(\Delta f_{t}<0\right)+\beta_{B 1} \Delta f_{t} I\left(\Delta f_{t}>0\right)_{t}+\beta_{2} \Delta f_{t} \times t+\beta_{3} \text { Opacity }_{i t}+ \\
& \beta_{G 4} \text { Opacity }_{i t} \times \Delta f_{t} I\left(\Delta f_{t}<0\right)+\beta_{B 4} \text { Opacity }_{i t} \times \Delta f_{t} I\left(\Delta f_{t}>0\right)+\gamma^{\prime} \mathbf{x}_{i t-1}^{e}+\varepsilon_{i t},
\end{aligned}
$$

for bonds and equities, respectively. I(.) are indicator variables which take value one if the condition inside the parenthesis is met and zero otherwise. The results for bond (Table 4) and equity returns (Table 6) go in opposite directions. For bond returns, higher opacity has a greater price-amplification effect for good shocks than for bad shocks; except for the PWC Opacity index and the Transparency of Government Policies index (ROSC is now insignificant for both types of shocks). For equity returns, we find that for all opacity measures, except Wilshire Accounting Standards, opacity has a stronger and more significant amplification effect for adverse shocks (ROSC has a significant interaction with good shocks, at the 10 percent level, but with the wrong sign).

\footnotetext{
${ }^{22}$ Amihud (2002) proposes as a measure of illiquidity the absolute (percentage) price change per dollar of daily trading volume, or the daily price impact of the order flow. This measure compares well to alternative measures of illiquidity as a proxy for price impact (Goyenko, Holden, and Trzinka, 2009). We define the illiquidity variable as the weekly average ratio of the daily absolute return to the (dollar) trading volume on that day. The measure is constructed using data from Datastream.

${ }^{23}$ Calvo and Mendoza (2000) argue that, in the presence of fixed costs of gathering and processing countryspecific information, increased market integration may exacerbate the international transmission of financial shocks by weakening incentives for acquiring such information and fostering herding. In such a setting, the cost of information gathering for small markets may exceed its benefits, so that smaller markets should be more responsive to global financial shocks. We explore this possibility by including an additional interaction of the VIX with local equity market capitalization, and our results regarding opacity do not change significantly. Results are available from the authors upon request.
} 
The result for the asymmetric response of equity returns complements previous work by Bae, Lim, and Wei (2006) on the role of corporate governance as a determinant of return asymmetries. In their study, the higher prevalence of return skewness in emerging markets is explained by the asymmetric release of information by firms with poor corporate governance. They find that, in countries with poor corporate governance, firms delay the release of bad information, which leads to extremely negative rates of return when such news is eventually released. One way to conciliate our findings with theirs is think that firms from high-opacity countries tend to release bad news during periods of increased global market turbulence (i.e. at the same time as a bad shock to the VIX). This is, however, a different mechanism than the one we are proposing in this study and should be the focus of future research.

\section{B. Endogeneity}

Potentially, our results could suffer from an endogeneity problem. For example, governments who have observed strong financial market volatility in their countries may (erroneously) believe that reducing transparency may help dampening large asset price swings. If this were the case, our inference - interpreting the causation as running from high opacity to volatility - would be invalid. While we do not consider this scenario to be very plausible, it is testable. For the opacity variables for which we have sufficient time variation, we can assess whether in fact lagged volatility induces a decline in transparency. ${ }^{24}$ For this effect, we perform a test of Granger causality using one measure of opacity with substantial time variation (the Corruption Perception Index by Transparency International) and the volatility of MSCI returns. We estimate a panel VAR with three lags, country and year fixed effects and these two variables, and test the joint hypothesis that, for the equation with opacity as the dependent variable, the coefficients of all three lags of volatility are zero. ${ }^{25}$ The results in Table 9 show that both for equities and bonds one cannot reject the null of volatility not Granger-causing opacity. We conclude that, at least in our data, endogeneity of opacity does not seem to be a problem.

\section{Conclusion}

In this paper we presented some thoughts and evidence on the role of transparency in amplifying shocks across markets. We provided a simple model formalizing the intuition that more opaque assets react more strongly to signals in financial centers. The evidence for

\footnotetext{
${ }^{24}$ If governments react to high volatility by increasing transparency, this would induce a bias against finding any effect of opacity. See Bhattacharya, Daouk, and Welker (2003) and Gelos and Wei (2005) for an exploration of opacity endogeneity in a different setting.

${ }^{25}$ The VAR is estimated by LSDV, which is consistent for fixed $N$.
} 
emerging bond and equity markets is consistent with this notion, and the effects are quantitatively important, lending support to the policy push for transparency. ${ }^{26}$

Regarding further research, extending the analysis to other cross-border capital flows such as bank lending could also provide important new insights. Another avenue would be to study the implications of our findings for contagion channels across domestic assets and institutions. It would also be fruitful to consider theoretical settings with heterogeneous information, to explore the robustness of our predictions in more general and richer models.

${ }^{26}$ Our theoretical model emphasizes the role of international investors without taking into account the role of domestic investors in emerging markets, for whom - in the presence of informational asymmetries - ambiguity about return distributions may be substantially lower (see Broner and others, 2012 for a recent discussion of informational asymmetries in the context of capital flows). The empirical results presented here suggest that any counteracting effect resulting from the behavior of domestic investors is outweighed by that of international ones. This seems consistent with the evidence (see, for example Calvo, Izquierdo, and Mejía, 2008). 


\section{Appendix A - Model Details And Proofs}

\section{A.1 - Joint and conditional distributions of signal and dividend processes}

Assuming the correlation $\rho$ between dividends paid by assets 1 and 2 is known, we have

$\operatorname{cov}\left(d_{1}, d_{2}\right)==\rho \sqrt{\sigma_{u 1}^{2}+\sigma_{b}^{2}} \sigma_{2}=\rho \tilde{\sigma}_{1} \sigma_{2}$, where $\tilde{\sigma}_{1}^{2} \equiv \sqrt{\sigma_{u 1}^{2}+\sigma_{b}^{2}}$. The joint distribution of the two dividend processes is given by $\boldsymbol{d} \sim N\left(M_{d}, V_{d}\right)$, where

$$
M_{d}=\left[\begin{array}{c}
\mu_{1}+\mu_{b} \\
\mu_{2}
\end{array}\right]
$$

and

$$
V_{d}=\left[\begin{array}{cc}
\tilde{\sigma}_{1}^{2} & \rho \tilde{\sigma}_{1} \sigma_{2} \\
- & \sigma_{2}^{2}+\sigma_{\varepsilon 2}^{2}
\end{array}\right]
$$

while the joint distribution of the two signals is $s \sim N\left(M_{s}, V_{s}\right)$, where $M_{s}=M_{d}$ and

$$
V_{s}=\left[\begin{array}{cc}
\tilde{\sigma}_{1}^{2}+\sigma_{\varepsilon 1}^{2} & \rho \tilde{\sigma}_{1} \sigma_{2} \\
- & \sigma_{2}^{2}+\sigma_{\varepsilon 2}^{2}
\end{array}\right]
$$

Given this and the joint distribution of $\mathbf{d}$ and $\mathbf{s}$,

$$
\left[\begin{array}{l}
\mathbf{d} \\
\mathbf{s}
\end{array}\right] \sim N\left(\left[\begin{array}{c}
M_{d} \\
M_{s}
\end{array}\right],\left[\begin{array}{cc}
V_{d} & C_{d s} \\
C_{d s}^{\prime} & V_{s}
\end{array}\right]\right)
$$

and normal Bayesian updating, it follows that the conditional distribution of $\boldsymbol{d}$ given $\boldsymbol{s}$ is normal and given by $\mathbf{d} \mid \mathbf{s} \sim N\left(M_{d}+C_{d s} V_{s}{ }^{-1} C_{d s}{ }^{\prime}\left(S-M_{s}\right), S_{d}-C_{d s} V_{s}{ }^{-1} C_{d s}{ }^{\prime}\right)$. Using the fact that the noise terms are orthogonal to the dividend processes, we can easily show that $C_{d s}=V_{d}$.

In the same fashion we can derive the distribution of $\mathbf{d}$, conditional on $J=\left[\begin{array}{ll}s^{\prime} & b\end{array}\right]^{\prime}$, to be normal with mean $M_{d}+C B^{-1} C^{\prime}\left(\mathrm{S}-\mathrm{M}_{s}\right)$ and variance $V_{d}-C B^{-1} C^{\prime}$, where $\mathrm{S}-\mathrm{M}_{s}=\left[s_{1}-\mu_{1}-\mu_{b}, s_{2}-\mu_{2}\right.$, $\left.b-\mu_{b}\right]^{\prime}, B=\left[\begin{array}{cc}V_{s} & \mathbf{x} \\ \mathbf{x}^{\prime} & \sigma_{b}^{2}\end{array}\right]$, and $C=\left[V_{d} \vdots \boldsymbol{x}\right]$, with $\boldsymbol{x}=\left[\sigma_{b}^{2} 0\right]^{\prime}$. 


\section{A.2 - Proofs}

Consider

$$
\frac{\partial \mathbf{p}}{\partial s_{2}}=\frac{\partial E(\mathbf{d} \mid \mathbf{s})}{\partial s_{2}}, 0<\phi_{1} \equiv \tilde{\sigma}_{1}^{2} /\left(\tilde{\sigma}_{1}^{2}+\sigma_{\varepsilon 1}{ }^{2}\right)<1 \text { and } 0<\phi_{2} \equiv \sigma_{2}^{2} /\left(\sigma_{2}^{2}+\sigma_{\varepsilon 2}^{2}\right)<1,
$$

which holds as long as the noise terms are nondegenerate. $\phi_{1}$ and $\phi_{2}$ are the signal-to-noise ratios of assets 1 and 2, respectively.

Lemma 1 Asset prices in the emerging market react positively (negatively) to positive (negative) news concerning the developed market if and only if the two dividend processes are positively correlated, i.e., $\partial p_{1} / \partial s_{2}>0$ if $\rho>0$.

\section{Proof.}

Using (2) and after taking derivatives with respect to $s_{2}$, we get (after some algebra):

$$
\frac{\partial p_{1}}{\partial s_{2}}=\rho \tilde{\sigma}_{1} \sigma_{2} \frac{\phi_{1}+\phi_{2}-\left(1+\rho^{2}\right) \phi_{1} \phi_{2}}{1-\rho^{2} \phi_{1} \phi_{2}}>\rho \tilde{\sigma}_{1} \sigma_{2} \frac{\phi_{1}+\phi_{2}-2 \phi_{1} \phi_{2}}{1-\rho^{2} \phi_{1} \phi_{2}} \text {, given }|\rho|<1 \text {. }
$$

It is clear that the numerator in the second fraction above is positive for $0<\phi_{i}<1, i \in\{1,2\}$ since $\phi_{1}>0>\left(\phi_{1}-1\right) \phi_{2}$. The denominator of said fraction is also positive for $0<\phi_{i}<1$. Therefore, the left-hand side of (A.1) is positive if $\rho>0$.

Proposition 1: If the fundamentals in the two markets are positively correlated $(\rho>0)$, the sensitivity of the price of asset 1 (emerging market) to a shock in the developed market (signal 2) is decreasing in the variance of the non fundamental shock to asset 1 . This means, $\frac{\partial^{2} p_{1}}{\partial s_{2} \partial \sigma_{\varepsilon 1}^{2}}<0$

\section{Proof.}

Using the equality in (A.1) and writing $\frac{\partial p_{1}}{\partial s_{2}}=\rho \tilde{\sigma}_{1} \sigma_{2} \chi$, with $\chi \equiv \frac{\phi_{1}+\phi_{2}-\left(1+\rho^{2}\right) \phi_{1} \phi_{2}}{1-\rho^{2} \phi_{1} \phi_{2}}$, it is easy to see that

$$
\frac{\partial \chi}{\partial \phi_{1}}=\frac{\left(1-\left(1+\rho^{2}\right) \phi_{2}\right)\left(1-\rho^{2} \phi_{1} \phi_{2}\right)-\left(\phi_{1}+\phi_{2}-\left(1+\rho^{2}\right) \phi_{1} \phi_{2}\right)\left(-\rho^{2} \phi_{2}\right)}{\left(1-\rho^{2} \phi_{1} \phi_{2}\right)^{2}}=\frac{\left(1-\phi_{2}\right)\left(1-\rho^{2} \phi_{2}\right)}{\left(1-\rho^{2} \phi_{1} \phi_{2}\right)^{2}}>0
$$

Therefore, 


$$
\frac{\partial^{2} p_{1}}{\partial s_{2} \partial \sigma_{\varepsilon 1}^{2}}=\frac{\partial^{2} p_{1}}{\partial s_{2} \partial \phi_{1}} \frac{\partial \phi_{1}}{\partial \sigma_{\varepsilon 1}^{2}}=\rho \tilde{\sigma}_{1} \sigma_{2} \frac{\partial \chi}{\partial \phi_{1}} \frac{\partial \phi_{1}}{\partial \sigma_{\varepsilon 1}^{2}}=\rho \tilde{\sigma}_{1} \sigma_{2} \frac{\left(1-\phi_{2}\right)\left(1-\rho^{2} \phi_{2}\right)}{\left(1-\rho^{2} \phi_{1} \phi_{2}\right)^{2}}\left(-\frac{1}{\left(\tilde{\sigma}_{1}^{2}+\sigma_{\varepsilon 1}^{2}\right)^{2}}\right)<0
$$

for $\rho>0$.

Proposition 2 The sensitivity of the price of asset 1 (emerging market) to a shock in the developed market (signal 2) is increasing in ambiguity (measured by the variance of the prior belief about b) as long as $\rho>0$.

\section{Proof:}

We want to show

$$
\frac{\partial^{2} p_{1}}{\partial s_{2} \partial \sigma_{b}^{2}}=\frac{\partial^{2} p_{1}}{\partial s_{2} \partial \tilde{\sigma}_{1}} \frac{\partial \tilde{\sigma}_{1}}{\sigma_{b}^{2}}>0
$$

We start by noting that $\frac{\partial \tilde{\sigma}_{1}}{\sigma_{b}^{2}}=2 \sigma_{\varepsilon 1}^{2} / \tilde{\sigma}_{1} \phi_{1}>0$. Thus it suffices that $\frac{\partial^{2} p_{1}}{\partial s_{2} \partial \tilde{\sigma}_{1}}>0$. Using the formula we derived above for $\partial p_{1} / \partial s_{2}$, we have:

$$
\frac{\partial^{2} p_{1}}{\partial s_{2} \partial \tilde{\sigma}_{1}}=\rho \sigma_{2} \underbrace{\frac{\phi_{1}+\phi_{2}-\left(1+\rho^{2}\right) \phi_{1} \phi_{2}}{1-\rho^{2} \phi_{1} \phi_{2}}}_{\equiv \chi}+\rho \tilde{\sigma}_{1} \sigma_{2} \frac{\partial \chi}{\partial \tilde{\sigma}_{1}} \text { and } \frac{\partial \chi}{\partial \tilde{\sigma}_{1}}=\frac{\partial \chi}{\partial \phi_{1}} \underbrace{\frac{\partial \phi_{1}}{\partial \tilde{\sigma}_{1}}}_{>0} \text {. }
$$

We know $\rho \sigma_{2} \chi>0$ by (A.1) in Lemma 1's proof and $\frac{\partial \chi}{\partial \phi_{1}}>0$ from (A.2) in Proposition 2's proof. Therefore, $\frac{\partial^{2} p_{1}}{\partial s_{2} \partial \sigma_{b}^{2}}>0$. 


\section{APPENDIX B - LIST OF COUNTRIES USED IN THE SAMPLE}

Argentina
Brazil
Chile
China
Colombia
Czech Republic
Egypt
Hong Kong SAR
Hungary
India
Indonesia
Israel
Jordan
Korea
Malaysia
Mexico
Morocco
Pakistan
Peru
Philippines
Poland
Russian Federation
Singapore
South Africa
Taiwan Province of China
Thailand
Turkey




\section{REFERENCES}

Albuquerque, Rui, Gregory H. Bauer, and Martin Schneider, 2009, “Global Private Information in International Equity Markets," Journal of Financial Economics 94, pp. 18-46.

Amihud, Yakov, 2002, "Illiquidity and stock returns: Cross Section and Time Series Effects." Journal of Financial Markets 5, pp. 31-36.

Amihud, Yakov, Haim Mendelson, and Lasse Pedersen, 2005, "Liquidity and Asset Prices." Foundations and Trends in Finance 1, pp. 269-364.

Ang, Andrew and Geert Bekaert, 2007, "Stock Return Predictability: Is it There?" Review of Financial Studies 20(3), pp. 651-707.

Bae, Kee-Hong, Chanwoo Lim, and K.C. John Wei, 2006, "Corporate Governance and Conditional Skewness in the World's Stock Markets." Journal of Business 79(6), pp. 2999-3028.

Bekaert, Geert, Michael Ehrmann, Marcel Fratzscher, and Arnaud J. Mehl, 2011, "Global Crises and Equity Market Contagion,” NBER Working Paper No. 17121, National Bureau of Economic Research.

Bekaert, Geert, and Campbell R. Harvey, 1995, "Time-varying World Market Integration." Journal of Finance 50(2), pp. 403-444.

Bekaert, Geert, and Campbell Harvey, 2000, "Foreign Speculators and Emerging Equity Markets.” Journal of Finance, pp. 565-613.

Bekaert, Geert, Campbell Harvey, and Angela Ng, 2005, "Market Integration and Contagion," Journal of Business, 78(1), pp. 39-69.

Bekaert, Geert, Campbell Harvey, Christian T. Lundblad, and Stephan Siegel, 2011, "What Segments Equity Markets?” The Review of Financial Studies 24(12), pp. 3841-3890.

Bekaert, Geert, Campbell Harvey, Christian T. Lundblad, and Stephan Siegel, 2012, "Political Risk and International Valuation." Available at SSRN 2022652.

Bhattacharya, Utpal, Hazem Daouk, and Michael Welker, 2003, "The World Price of Earnings Opacity.” The Accounting Review: July 2003, Vol. 78, No. 3, pp. 641-678.

Bodnar, Gordon M. and M. H. Franco Wong, 2003, "Estimating Exchange Rate Exposures: Issues in Model Structure.” Financial Management, v. 32, no. 1, pp. 35-67.

Bollersllev, Tim, George Tauchen and Zhou, 2009, "Expected Stock Returns and Variance Risk Premia," The Review of Financial Studies, 22(11), pp. 4463-4492.

Broner, Fernando A., Gaston Gelos, and Carmen M. Reinhart, 2006, "When in Peril, Retrench: Testing The Portfolio Channel of Contagion," Journal of International Economics 69(1), pp. $203-230$. 
Broner, Fernando A., Tatiana Didier, Aitor Erce, and Sergio Schmukler, 2011, "Gross Capital Flows: Dynamics and Crises," CEPR Discussion Papers 8591.

Brunnermeier, Markus K., and Lasse Heje Pedersen, 2009. "Market Liquidity and Funding Liquidity." Review of Financial studies 22(6), pp. 2201-2238.

Cady, John, and Anthony Pellechio, 2008, "Sovereign Borrowing cost and the Data Dissemination Initiative." The IMF's Data Dissemination Initiative after 10 Years, edited by William E. Alexander, John Cady, and Jesus Gonzalez-Garcia, pp. 92-112. (Washington, D.C.: International Monetary Fund)

Calvo, Guillermo, Alejandro Izquierdo, and Luis-Fernando Mejía, 2008, "Systemic Sudden Stops: The Relevance of Balance-Sheet Effects And Financial Integration." NBER Working Paper No. 14026.

Calvo, Guillermo A., and Enrique G. Mendoza, 2000. "Rational Contagion and the Globalization of Securities Markets.” Journal of International Economics 51, no. 1, pp. 79-113.

Caskey, Judson A., 2009, "Information in Equity Markets with Ambiguity-averse Investors." Review of Financial Studies 22(9), pp. 3595-3627.

Claessens, Stijn, 2009, "Lessons from the Recent Financial Crisis for Reforming National and International Financial Systems," keynote paper presented at the Annual Bank Conference for Development Economics, Seoul, Korea.

Claessens, Stijn, and B. Burcin Yurtuglo, 2012, "Corporate Governance in Emerging Markets: A Survey," Emerging Markets Review, March.

Comelli, Fabio, 2012, "Emerging Market Sovereign Bond Spreads: Estimation and Backtesting.” Emerging Markets Review 13, pp. 598-625.

De Jong, F. and F. A. De Roon, 2005, “Time-varying Market Integration and Expected Returns in Emerging Markets," Journal of Financial Economics 78(3), pp. 583 - 613.

Didier, Tatiana, Inessa Love, and Maria Soledad Martínez Pería, 2012, "What Explains Stock Markets' Vulnerability to the 2007-2008 Crisis?” Policy Research Working Paper 5224. World Bank.

Djankov, Simeon, Rafael La Porta, Florencio Lopez-de-Silanes, and Andrei Shleifer, 2008, "The Law and Economics of Self-dealing." Journal of Financial Economics 88(3), pp. 430 465. Darden - JFE Conference Volume: Capital Raising in Emerging Economies.

Doidge, Craig, G. Andrew Karolyi, and René M. Stulz, 2007, "Why Do Countries Matter So Much for Corporate Governance?” Journal of Financial Economics, 86(1), pp. 1-39,

Dominguez, Kathryn M.E. and Linda L. Tesar, 2006, “Exchange Rate Exposure.” Journal of International Economics, 68(1), pp. 188-218.

Drees, Burkhard, Bernhard Eckwert, and Felix Vardy, 2013, "Cheap Money and Risk Taking: Opacity versus Fundamental Risk.” European Economic Review, 62, pp. 114-129.

Driscoll, John C. and Aaart. C. Kraay, 1998, "Consistent Covariance Matrix Estimation with Spatially Dependent Panel Data." Review of Economics and Statistics, 80(4), pp. 549-560. 
Dumas, Bernard and Bruno Solnik, 1995, "The World Price of Foreign Exchange Risk." The Journal of Finance, Vol. 50, No. 2, pp. 445-479.

Easley, David and Maureen O' Hara, 2009, “Ambiguity and Nonparticipation: The Role of Regulation," The Review of Financial Studies 22(5), pp. 1817-1843.

Errunza, Vihang and Etienne Losq, 1985, “International Asset Pricing Under Mild Segmentation: Theory and Test.” Journal of Finance, 40, pp. 105- 124.

Forbes, Kristin, 2012, “The Big C: Identifying and Mitigating Contagion.” MIT Sloan School Working Paper 4970-12.

Forbes, Kristin and Menzie Chinn, 2004, "A Decomposition of Global Linkages in Financial Markets over Time," Review of Economics and Statistics, 86(3), pp. 705-722.

Fratzscher, Marcel, 2012, "Capital Flows, Push versus Pull Factors, and the Global Financial Crisis.” Journal of International Economics, (88)2, pp. 341-356.

Fratzscher, Marcel, and Jean Imbs, 2009, "Finance, Institutions, and Risk Sharing in International Portfolios,” Journal of Financial Economics, 94(3), pp. 428-447.

Frenkel, Michael and Lukas Menkhoff, 2004, "Are Foreign Institutional Investors Good for Emerging Markets?” The World Economy, Vol. 27, No.8, pp. 1275-1293.

Furman, Jason, Josepg E. Stiglitz, Barry P. Bosworth, and Steven Radelet, 1998, "Economic Crises: Evidence and Insights from East Asia," Brookings Papers on Economic Activity 1998(2), pp. 1-135.

Gai, Prasanna, 2003, "Transparency and Financial Stability.” Financial Stability Review, Bank of England.

Gande, Amar and David Parsley, 2007, "Sovereign Credit Ratings, Transparency, and International Portfolio Flows," mimeo, Vanderbilt University.

Gelos, Gaston and Shang-Jin Wei, 2005, “Transparency and International Portfolio Holdings." The Journal of Finance 60(6), pp. 2987-3020.

Glennerster, Rachel and Yongseuk Shing, 2008, “Does Transparency Pay?,” IMF Staff Papers, Vol. 55 No. 1, pp. 182-209.

Goldstein, Morris, 1998, “The Asian Financial Crisis: Causes, Cures, and Systemic Implications," Institute for International Economics.

Gollier, C., 2011, "Portfolio Choices and Asset Prices: The Comparative Statics Of Ambiguity Aversion,” Review of Economic Studies 78(4), pp. 1329-1344.

González Rosada, Martín and Eduardo Levy-Yeyati, 2008, "Global Factors and Emerging Market Spreads,” The Economic Journal, Vol. 118, No. 533, pp. 1917-1936.

Goyenko, R. Y., C. W. Holden, and C. A. Trzinka, 2009, "Do Liquidity Measures Measure Liquidity?" Journal of Financial Economics, 92, pp. 153-181. 
Hartelius, Kristian, Kenichiro Kashiwase, and Laura Kodres, 2008, "Emerging Market Spread Compression: Is it Real or is it Liquidity?” IMF Working Paper 08/10.

Hashimoto, Yuko, and Konstantin Wacker.2012. "The Role of Risk and Information for International Capital Flows: New Evidence from the SDDS. IMF Working Paper No. 12/242. International Monetary Fund, 2001, IMF Survey Supplement 30, September, Washington, D.C., pp. $7-8$.

Jaramillo, Laura, and Michelle Tejada, 2011, "Sovereign Credit Ratings and Spreads in Emerging Markets: Does Investment Grade Matter?” IMF Working Paper No. 11/44.

Johnson, Simon, Peter Boone, Alasdair Breach, and Eric Friedman, 2000, "Corporate governance in the Asian financial crisis." Journal of Financial Economics 58(1), pp. 141-186.

Hong, Harrison, and David Sraer, 2012, "Speculative Betas.” NBER Working Paper No. 18548.

Kodres, Laura and Matthew Pritsker, 2002, “A Rational Expectations Model of Financial Contagion,” Journal of Finance, 57(2), pp. 769-799.

Klibanoff, Peter, Massimo Marinacci, and Sujoy Mukerji, 2005, "A Smooth Model Of Decision-making under Ambiguity,” Econometrica 73(6), pp. 1849-1892.

Kurtzman, Joel, T. Phumiwasana, and G. Yago, 2004, "The Global Costs of Opacity," MIT Sloan Management Review, 46(1), pp.38-44.

Kurtzman, Joel and G. Yago, 2008, “Opacity Index 2007-2008: Measuring Global Business Risks," The Milken Institute.

Kurtzman, Joel and G. Yago, 2009, “Opacity Index 2009: Measuring Global Business Risks," The Milken Institute.

Lang, Mark and Mark Maffett, 2011, "Transparency and Liquidity Uncertainty in Crisis Periods," Journal of Accounting and Economics, Volume 52, Issues 2-3, pp. 101-125.

Lang, Mark, KV Lins, and Mark Maffet, 2012, “Transparency, Liquidity, and Valuation: International Evidence on When Transparency Matters Most," Journal of Accounting Research Vol. 50, No. 3, pp. 729-774.

Morris, Stephen and Hyun Song Shin, 2002, "Social Value of Public Information." The American Economic Review 92(5), pp. 1521-1534.

Morris, Stephen, Hyun Son Shin, and Hui Tong, 2006, "Social Value of Public Information: Morris and Shin 16(2002) is Actually Pro-transparency, not Con: Reply." The American Economic Review 96(1), pp. 453-455.

PricewaterhouseCoopers, 2001, The Opacity Index, Available at: $\underline{\text { www.opacityindex.com. }}$

Transparency International, 2001, Corruption Perception Index, Available at: www.transparency.org. 
Wei, Shang Jin and Yi Yu, 2002, "Negative Alchemy? Corruption, Composition of Capital Flows, and Currency Crises." In Preventing Currency Crises in Emerging Markets, Sebastian Edwards and Jeffrey A. Frankel (eds.), pp. 461-506 (Chicago: University of Chicago Press).

Wilshire Associates, various years, Permissible Equity Markets Investment Analysis and Recommendations, Prepared for The California Public Employees' Retirement System.

World Economic Forum, various years, The Global Competitiveness Report, Geneva. 


\section{Table 1 - Correlations between Measures of Opacity, Risk, and Liquidity}

Table shows linear correlations between different measures of opacity, country risk, and liquidity. PWC Opacity Index is PricewaterhouseCoopers' Opacity Index. Corruption Perceptions is Transparency International's Country Transparency index. Corporate Opacity is the Corporate Opacity Index from the Global Competitiveness Report (World Economic Forum). Wilshire Score (Accounting Standards) is the Accounting Standards factor in the Wilshire Score from Wilshire Associates. Disclosure is Djankov, and others' (2008) index of disclosure in periodic filings' component of its Anti-self-dealing index. Government Policies is the Transparency of Government Policies Index from the Global Competitiveness Report (World Economic Forum). ROSC Publication takes value one if the country has never published a ROSC report and zero otherwise. SNP is Standard \& Poor's Rating and Outlook. ICRG Country Risk Rating is the Composite Risk Rating from ICRG. Illiquidity is Amihud's (2002) measure of market illiquidity. If needed, indices were multiplied by -1 so as to reflect increasing level of opacity.

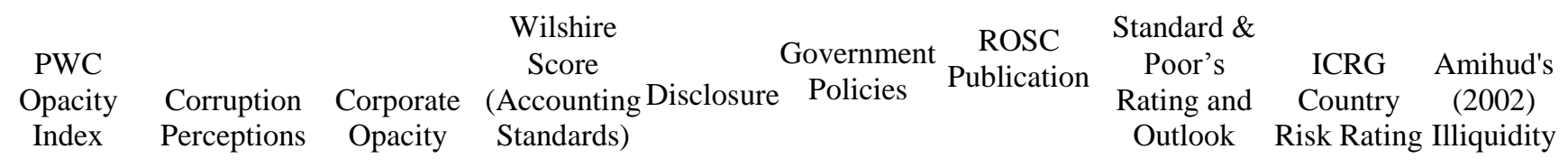

\section{PWC Opacity Index}

Corruption Perceptions

Corporate Opacity

Wilshire Score (Accounting Standards)

Disclosure

Government Policies

ROSC Publication

Standard \& Poor's Rating and Outlook

ICRG Country Risk Rating

Illiquidity

\section{1}

0.58

0.43

$-0.06$

0.15

0.46

0.22

0.51

$-0.35$

0.24

1
0.71
0.03
0.43
0.52
0.27
0.60
-0.42
0.09

\section{1}

0.71

0.03

0.43

0.52

0.27

0.60

$-0.42$

0.09

1
0.02
0.38
0.44
0.21
0.13
-0.01
0.02

$\begin{array}{rr}1 & \\ -0.02 & 1 \\ 0.00 & 0.53 \\ -0.24 & 0.05 \\ 0.08 & 0.29 \\ -0.20 & -0.23 \\ -0.09 & -0.06\end{array}$

$\begin{array}{rrr}-0.04 & 1 & \\ 0.53 & 0.11 & 1 \\ -0.25 & -0.15 & -0.71 \\ 0.24 & 0.02 & 0.26\end{array}$

$\begin{array}{rrr}-0.04 & 1 & \\ 0.53 & 0.11 & 1 \\ -0.25 & -0.15 & -0.71 \\ 0.24 & 0.02 & 0.26\end{array}$

$\begin{array}{rrr}-0.04 & 1 & \\ 0.53 & 0.11 & 1 \\ -0.25 & -0.15 & -0.71 \\ 0.24 & 0.02 & 0.26\end{array}$

1
-0.14 


\section{Table 2 - Summary Statistics}

Table shows summary statistics for bond and equity returns (EMBIG and MSCI), VIX changes, and opacity indices. PWC Opacity Index is PricewaterhouseCoopers' Opacity Index. Corruption Perceptions is Transparency International's Country Transparency index. Corporate Opacity is the Corporate Opacity Index from the Global Competitiveness Report (World Economic Forum). Wilshire Score (Accounting Standards) is the Accounting Standards factor in the Wilshire Score from Wilshire Associates. Disclosure is Djankov, and others' (2008) index of disclosure in periodic filings' component of its Anti-self-dealing index. Government Policies is the Transparency of Government Policies Index from the Global Competitiveness Report (World Economic Forum). ROSC Publication takes value one if the country has never published a ROSC report and zero otherwise. $\mathrm{P} 10 \%, \mathrm{P} 50 \%$, and $\mathrm{P} 90 \%$ are the $10^{\text {th }}, 50^{\text {th }}$, and $90^{\text {th }}$ percentiles.

\begin{tabular}{lrrrrr} 
Variables & Mean & \multicolumn{1}{c}{ S.D. } & \multicolumn{1}{c}{ P10\% } & \multicolumn{1}{c}{ P50\% } & \multicolumn{1}{c}{ P90\% } \\
\hline$\Delta$ EMBIG & $0.37 \%$ & $8.85 \%$ & $-8.45 \%$ & $-0.22 \%$ & $9.40 \%$ \\
$\Delta$ MSCI & $0.14 \%$ & $4.56 \%$ & $-5.00 \%$ & $0.21 \%$ & $5.19 \%$ \\
$\Delta$ VIX & $0.80 \%$ & $12.77 \%$ & $-12.97 \%$ & $-0.45 \%$ & $15.83 \%$ \\
PWC Opacity Index & 46.72 & 15.59 & 29.00 & 45.00 & 67.00 \\
Corruption Perceptions & 5.66 & 1.75 & 2.72 & 6.20 & 7.50 \\
Corporate Opacity & 3.20 & 0.63 & 2.05 & 3.25 & 3.95 \\
Wilshire Score (Accounting Standards) & 2.36 & 0.62 & 1.00 & 2.50 & 3.00 \\
Disclosure & 0.41 & 0.33 & 0.00 & 0.40 & 0.80 \\
Government Policies & 2.86 & 0.85 & 1.79 & 2.90 & 3.90 \\
ROSC Publication & 0.45 & 0.50 & 0.00 & 0.00 & 1.00 \\
\hline
\end{tabular}




\section{Table 3 - Global Shocks, Bond Returns and Transparency: Linear Effects}

The dependent variable is weekly change in the bond spread implicit on each country EMBIG index, winsorized at the top and bottom 0.5 percentile. Table shows the baseline linear effects specification with country and year fixed effects and Driscoll-Kraay standard errors. SNP is Standard \& Poor's Rating and Outlook (transformed to index and orthogonalized with respect to opacity variable). Opacit is PWC Opacity Index. Corrup is Transparency International's Country Transparency index. Corpop is the Corporate Opacity Index from the Global Competitiveness Report (World Economic Forum). $\mathrm{W}_{a s}$ is the Accounting Standards factor in the Wilshire Score from Wilshire Associates. Disclosure is Djankov, and others' (2008) index of disclosure in periodic filings' component of its Anti-self-dealing index. TGP is the Transparency of Government Policies index by the World Economic Forum. ROSC is a dummy for the publication of a country's first ROSC report. If needed, indices were normalized so as to reflect increasing level of opacity. $\mathrm{p}$-value in parentheses: $* * * \mathrm{p}<0.01, * *$ $\mathrm{p}<0.05, * \mathrm{p}<0.1$.

Dependent variable: $\triangle \mathrm{EMBIG}_{i, t}$

\begin{tabular}{|c|c|c|c|c|c|c|c|}
\hline Variables & $\begin{array}{c}(1) \\
\text { Opacit }\end{array}$ & $\begin{array}{c}(2) \\
\text { Corrup }\end{array}$ & $\begin{array}{c}(3) \\
\text { Corpop }\end{array}$ & $\begin{array}{c}(4) \\
W_{a s}\end{array}$ & $\begin{array}{c}(5) \\
\text { Disclosure }\end{array}$ & $\begin{array}{c}6) \\
\text { TGP }\end{array}$ & $\begin{array}{c}(7) \\
\text { ROSC }\end{array}$ \\
\hline$\Delta$ on-off spread & $\begin{array}{c}0.0398^{* *} \\
(0.014)\end{array}$ & $\begin{array}{c}0.0388^{\star *} \\
(0.013)\end{array}$ & $\begin{array}{c}0.0396^{* *} \\
(0.015)\end{array}$ & $\begin{array}{c}0.0390^{* *} \\
(0.012)\end{array}$ & $\begin{array}{c}0.0392^{\star *} \\
(0.012)\end{array}$ & $\begin{array}{c}0.0453^{* *} \\
(0.039)\end{array}$ & $\begin{array}{c}0.0393^{* *} \\
(0.012)\end{array}$ \\
\hline$\Delta \mathrm{iUS}_{\mathrm{U}} \mathrm{mo}_{t}$ & $\begin{array}{l}-0.0030 \\
(0.244)\end{array}$ & $\begin{array}{l}-0.0029 \\
(0.254)\end{array}$ & $\begin{array}{c}-0.0031 \\
(0.254)\end{array}$ & $\begin{array}{c}-0.0029 \\
(0.253)\end{array}$ & $\begin{array}{c}-0.0029 \\
(0.256)\end{array}$ & $\begin{array}{c}-0.0024 \\
(0.338)\end{array}$ & $\begin{array}{c}-0.0029 \\
(0.255)\end{array}$ \\
\hline Bond Restrictions & $\begin{array}{c}-0.0014 \\
(0.389)\end{array}$ & $\begin{array}{r}-0.0011 \\
(0.485)\end{array}$ & $\begin{array}{c}-0.0002 \\
(0.903)\end{array}$ & $\begin{array}{r}-0.0007 \\
(0.675)\end{array}$ & $\begin{array}{c}-0.0008 \\
(0.644)\end{array}$ & $\begin{array}{l}-0.0024 \\
(0.272)\end{array}$ & $\begin{array}{c}-0.0006 \\
(0.726)\end{array}$ \\
\hline Banking Crisis & $\begin{array}{l}0.0081 \\
(0.309)\end{array}$ & $\begin{array}{l}0.0058 \\
(0.460)\end{array}$ & $\begin{array}{l}0.0061 \\
(0.436)\end{array}$ & $\begin{array}{l}0.0056 \\
(0.478)\end{array}$ & $\begin{array}{l}0.0059 \\
(0.457)\end{array}$ & & $\begin{array}{l}0.0059 \\
(0.449)\end{array}$ \\
\hline Currency Crisis & $\begin{array}{l}-0.0001 \\
(0.989)\end{array}$ & $\begin{array}{l}0.0000 \\
(0.991)\end{array}$ & $\begin{array}{c}-0.0005 \\
(0.903)\end{array}$ & $\begin{array}{c}-0.0002 \\
(0.966)\end{array}$ & $\begin{array}{l}0.0001 \\
(0.990)\end{array}$ & $\begin{array}{c}-0.0006 \\
(0.950)\end{array}$ & $\begin{array}{c}-0.0003 \\
(0.948)\end{array}$ \\
\hline Debt Crisis & $\begin{array}{l}0.0400^{*} \\
(0.059)\end{array}$ & $\begin{array}{c}0.0419^{* *} \\
(0.045)\end{array}$ & $\begin{array}{c}0.0426^{\star *} \\
(0.045)\end{array}$ & $\begin{array}{c}0.0425^{\star *} \\
(0.044)\end{array}$ & $\begin{array}{c}0.0421^{\star *} \\
(0.046)\end{array}$ & & $\begin{array}{c}0.0419 * * \\
(0.047)\end{array}$ \\
\hline$\triangle \mathrm{XRATE}$ & $\begin{array}{c}0.3279^{* * *} \\
(0.000)\end{array}$ & $\begin{array}{c}0.3332^{* * *} \\
(0.000)\end{array}$ & $\begin{array}{c}0.3251^{* * *} \\
(0.000)\end{array}$ & $\begin{array}{c}0.3265^{\star * *} \\
(0.000)\end{array}$ & $\begin{array}{c}0.3180^{* * *} \\
(0.000)\end{array}$ & $\begin{array}{c}0.2749^{* * *} \\
(0.000)\end{array}$ & $\begin{array}{c}0.3270^{* * *} \\
(0.000)\end{array}$ \\
\hline$\Delta \mathrm{VIX}$ & $\begin{array}{r}-0.1091 \\
(0.192)\end{array}$ & $\begin{array}{c}-0.0855 \\
(0.133)\end{array}$ & $\begin{array}{c}-0.1031 \\
(0.117)\end{array}$ & $\begin{array}{l}0.0229 \\
(0.717)\end{array}$ & $\begin{array}{l}0.0193 \\
(0.716)\end{array}$ & $\begin{array}{c}-0.1585^{\star *} \\
(0.043)\end{array}$ & $\begin{array}{l}0.0152 \\
(0.786)\end{array}$ \\
\hline$\Delta \mathrm{VIX} \times t$ & $\begin{array}{c}0.0004^{* * *} \\
(0.001)\end{array}$ & $\begin{array}{c}0.0003^{* * *} \\
(0.006)\end{array}$ & $\begin{array}{c}0.0004^{* * *} \\
(0.002)\end{array}$ & $\begin{array}{c}0.0003^{* * *} \\
(0.003)\end{array}$ & $\begin{array}{c}0.0003^{* * *} \\
(0.004)\end{array}$ & $\begin{array}{c}0.0005^{\star * *} \\
(0.000)\end{array}$ & $\begin{array}{c}0.0004^{* * *} \\
(0.001)\end{array}$ \\
\hline Opacity & $\begin{array}{c}-0.0002^{*} \\
(0.065)\end{array}$ & $\begin{array}{c}-0.0008 \\
(0.596)\end{array}$ & $\begin{array}{c}-0.0018 \\
(0.400)\end{array}$ & $\begin{array}{c}-0.0005 \\
(0.683)\end{array}$ & & $\begin{array}{l}0.0012 \\
(0.563)\end{array}$ & $\begin{array}{c}-0.0012 \\
(0.580)\end{array}$ \\
\hline VIX×Opacity & $\begin{array}{c}0.0028^{* * *} \\
(0.010)\end{array}$ & $\begin{array}{c}0.0352^{* * *} \\
(0.000)\end{array}$ & $\begin{array}{c}0.0336^{\star * *} \\
(0.008)\end{array}$ & $\begin{array}{c}-0.0096 \\
(0.453)\end{array}$ & $\begin{array}{c}0.1033^{* * *} \\
(0.000)\end{array}$ & $\begin{array}{c}0.0323^{\star *} \\
(0.015)\end{array}$ & $\begin{array}{c}0.0308^{*} \\
(0.061)\end{array}$ \\
\hline SNP & $\begin{array}{l}-0.0001 \\
(0.503)\end{array}$ & $\begin{array}{l}-0.0001 \\
(0.334)\end{array}$ & $\begin{array}{c}-0.0001 \\
(0.270)\end{array}$ & $\begin{array}{l}-0.0001 \\
(0.311)\end{array}$ & $\begin{array}{l}-0.0001 \\
(0.274)\end{array}$ & $\begin{array}{c}-0.0002 \\
(0.191)\end{array}$ & $\begin{array}{r}-0.0001 \\
(0.286)\end{array}$ \\
\hline$\Delta \mathrm{VIX} \times \mathrm{SNP}$ & $\begin{array}{c}-0.0005 \\
(0.541)\end{array}$ & $\begin{array}{c}-0.0020^{*} \\
(0.052)\end{array}$ & $\begin{array}{l}0.0013 \\
(0.137)\end{array}$ & $\begin{array}{l}0.0005 \\
(0.518)\end{array}$ & $\begin{array}{r}-0.0002 \\
(0.776)\end{array}$ & $\begin{array}{l}-0.0001 \\
(0.936)\end{array}$ & $\begin{array}{l}0.0005 \\
(0.521)\end{array}$ \\
\hline vations & 11,214 & 11,879 & 11,040 & 11,931 & 11,931 & 9,155 & 11,931 \\
\hline Number of countries & 19 & 21 & 19 & 21 & 21 & 21 & 21 \\
\hline
\end{tabular}


Table 4 - Global Shocks, Bond Returns and Transparency: Asymmetric Effects

The dependent variable is weekly change in the bond spread implicit on each country EMBIG index, winsorized at the top and bottom 0.5 percentile. Table shows the asymmetric effects specification with country and year fixed effects and Driscoll-Kraay standard errors. $\Delta \mathrm{VIX}_{G}$ and $\Delta \mathrm{VIX}_{B}$ stand for good (decrease) and bad (increase) volatility shocks (measured by VIX). SNP is Standard \& Poor's Rating and Outlook (transformed to index and orthogonalized with respect to opacity variable). Opacit is PWC Opacity Index. Corrup is Transparency International's Country Transparency index. Corpop is the Corporate Opacity Index from the Global Competitiveness Report (World Economic Forum). $\mathrm{W}_{\text {as }}$ is the Accounting Standards factor in the Wilshire Score from Wilshire Associates. Disclosure is Djankov, and others' (2008) index of disclosure in periodic filings' component of its Anti-self-dealing index. TGP is the Transparency of Government Policies index by the World Economic Forum. ROSC is a dummy for the publication of a country's first ROSC report. If needed, indices were normalized so as to reflect increasing level of opacity. If needed, indices were normalized so as to reflect increasing level of opacity. $P$-value in parentheses: $* * * p<0.01, * * p<0.05, * p<0.1$.

\begin{tabular}{|c|c|c|c|c|c|c|c|}
\hline \multicolumn{8}{|c|}{ Dependent variable: $\Delta \mathrm{EMBIG}_{i, t}$} \\
\hline Variables & $\begin{array}{c}(1) \\
\text { Onacit }\end{array}$ & $\begin{array}{l}(2) \\
\text { Corrun }\end{array}$ & $\begin{array}{c}\text { (3) } \\
\text { Cornon }\end{array}$ & (4) & $\begin{array}{c}\text { (5) } \\
\text { Disclosure }\end{array}$ & $\begin{array}{c}(6) \\
T G P\end{array}$ & $\begin{array}{c}(7) \\
R O S C\end{array}$ \\
\hline$\Delta$ on-off spread & $\begin{array}{c}0.0398^{\star *} \\
(0.014)\end{array}$ & $\begin{array}{c}0.0388^{* *} \\
(0.013)\end{array}$ & $\begin{array}{c}0.0395^{\star *} \\
(0.015)\end{array}$ & $\begin{array}{c}0.0390^{* *} \\
(0.012)\end{array}$ & $\begin{array}{c}0.0391^{* *} \\
(0.012)\end{array}$ & $\begin{array}{c}0.0457^{\star *} \\
(0.039)\end{array}$ & $\begin{array}{c}0.0392^{* *} \\
(0.012)\end{array}$ \\
\hline$\Delta \mathrm{iUS} 3 \mathrm{mo}_{t}$ & $\begin{array}{l}-0.0030 \\
(0.244)\end{array}$ & $\begin{array}{c}-0.0029 \\
(0.254)\end{array}$ & $\begin{array}{r}-0.0031 \\
(0.254)\end{array}$ & $\begin{array}{c}-0.0029 \\
(0.252)\end{array}$ & $\begin{array}{c}-0.0029 \\
(0.255)\end{array}$ & $\begin{array}{c}-0.0024 \\
(0.338)\end{array}$ & $\begin{array}{c}-0.0029 \\
(0.255)\end{array}$ \\
\hline Bond Restrictions & $\begin{array}{l}-0.0014 \\
(0.378)\end{array}$ & $\begin{array}{r}-0.0011 \\
(0.491)\end{array}$ & $\begin{array}{c}-0.0002 \\
(0.886)\end{array}$ & $\begin{array}{l}-0.0007 \\
(0.703)\end{array}$ & $\begin{array}{c}-0.0008 \\
(0.635)\end{array}$ & $\begin{array}{c}-0.0024 \\
(0.267)\end{array}$ & $\begin{array}{l}-0.0006 \\
(0.749)\end{array}$ \\
\hline Banking Crisis & $\begin{array}{l}0.0081 \\
(0.310)\end{array}$ & $\begin{array}{l}0.0059 \\
(0.456)\end{array}$ & $\begin{array}{l}0.0061 \\
(0.436)\end{array}$ & $\begin{array}{l}0.0056 \\
(0.482)\end{array}$ & $\begin{array}{l}0.0059 \\
(0.455)\end{array}$ & & $\begin{array}{l}0.0059 \\
(0.452)\end{array}$ \\
\hline Currency Crisis & $\begin{array}{l}-0.0001 \\
(0.988)\end{array}$ & $\begin{array}{l}0.0001 \\
(0.976)\end{array}$ & $\begin{array}{c}-0.0005 \\
(0.909)\end{array}$ & $\begin{array}{c}-0.0002 \\
(0.968)\end{array}$ & $\begin{array}{l}0.0001 \\
(0.989)\end{array}$ & $\begin{array}{c}-0.0009 \\
(0.920)\end{array}$ & $\begin{array}{r}-0.0002 \\
(0.958)\end{array}$ \\
\hline Debt Crisis & $\begin{array}{l}0.0401^{*} \\
(0.058)\end{array}$ & $\begin{array}{c}0.0418^{* *} \\
(0.045)\end{array}$ & $\begin{array}{c}0.0426^{* *} \\
(0.045)\end{array}$ & $\begin{array}{c}0.0426^{* *} \\
(0.044)\end{array}$ & $\begin{array}{c}0.0421^{* *} \\
(0.046)\end{array}$ & & $\begin{array}{c}0.0419^{* *} \\
(0.046)\end{array}$ \\
\hline$\triangle \mathrm{XRATE}$ & $\begin{array}{c}0.3277^{* * *} \\
(0.000)\end{array}$ & $\begin{array}{c}0.3322^{* * *} \\
(0.000)\end{array}$ & $\begin{array}{c}0.3245^{* * *} \\
(0.000)\end{array}$ & $\begin{array}{c}0.3266^{* * *} \\
(0.000)\end{array}$ & $\begin{array}{c}0.3182^{* * *} \\
(0.000)\end{array}$ & $\begin{array}{c}0.2762^{* * *} \\
(0.000)\end{array}$ & $\begin{array}{c}0.3256^{* * *} \\
(0.000)\end{array}$ \\
\hline$\Delta \mathrm{VIX} \times t$ & $\begin{array}{c}0.0004^{\star * *} \\
(0.001)\end{array}$ & $\begin{array}{c}0.0003^{* * *} \\
(0.006)\end{array}$ & $\begin{array}{c}0.0004^{* * *} \\
(0.002)\end{array}$ & $\begin{array}{c}0.0003^{\star * *} \\
(0.003)\end{array}$ & $\begin{array}{c}0.0003^{* * *} \\
(0.004)\end{array}$ & $\begin{array}{c}0.0005^{\star * \star} \\
(0.000)\end{array}$ & $\begin{array}{c}0.0004^{* * *} \\
(0.001)\end{array}$ \\
\hline SNP & $\begin{array}{c}-0.0001 \\
(0.537)\end{array}$ & $\begin{array}{r}-0.0001 \\
(0.319)\end{array}$ & $\begin{array}{l}-0.0001 \\
(0.267)\end{array}$ & $\begin{array}{l}-0.0001 \\
(0.303)\end{array}$ & $\begin{array}{l}-0.0001 \\
(0.268)\end{array}$ & $\begin{array}{c}-0.0002 \\
(0.210)\end{array}$ & $\begin{array}{r}-0.0001 \\
(0.274)\end{array}$ \\
\hline$\Delta \mathrm{VIX} \times \mathrm{SNP}$ & $\begin{array}{l}-0.0005 \\
(0.538)\end{array}$ & $\begin{array}{c}-0.0020^{*} \\
(0.051)\end{array}$ & $\begin{array}{l}0.0013 \\
(0.138)\end{array}$ & $\begin{array}{l}0.0005 \\
(0.522)\end{array}$ & $\begin{array}{c}-0.0002 \\
(0.769)\end{array}$ & $\begin{array}{r}-0.0001 \\
(0.946)\end{array}$ & $\begin{array}{l}0.0005 \\
(0.525)\end{array}$ \\
\hline Opacity & $\begin{array}{c}-0.0003^{*} \\
(0.085)\end{array}$ & $\begin{array}{l}0.0000 \\
(0.988)\end{array}$ & $\begin{array}{l}-0.0019 \\
(0.398)\end{array}$ & $\begin{array}{l}0.0013 \\
(0.533)\end{array}$ & & & $\begin{array}{l}-0.0031 \\
(0.405)\end{array}$ \\
\hline$\Delta \mathrm{VIX}_{G}$ & $\begin{array}{c}-0.0418 \\
(0.739)\end{array}$ & $\begin{array}{c}-0.1595^{\star *} \\
(0.048)\end{array}$ & $\begin{array}{c}-0.1442^{*} \\
(0.083)\end{array}$ & $\begin{array}{l}0.0615 \\
(0.506)\end{array}$ & $\begin{array}{r}-0.0041 \\
(0.942)\end{array}$ & $\begin{array}{r}-0.0897 \\
(0.425)\end{array}$ & $\begin{array}{l}0.0221 \\
(0.730)\end{array}$ \\
\hline$\Delta \mathrm{VIX}_{G \times} \times$ Opacity & $\begin{array}{l}0.0012 \\
(0.533)\end{array}$ & $\begin{array}{c}0.0469^{* * *} \\
(0.000)\end{array}$ & $\begin{array}{c}0.0444^{* *} \\
(0.023)\end{array}$ & $\begin{array}{l}0.0167 \\
(0.609)\end{array}$ & $\begin{array}{c}0.1441^{* * *} \\
(0.002)\end{array}$ & $\begin{array}{l}0.0123 \\
(0.612)\end{array}$ & $\begin{array}{l}0.0029 \\
(0.940)\end{array}$ \\
\hline$\Delta \mathrm{VIX}_{B}$ & $\begin{array}{c}-0.1456 \\
(0.108)\end{array}$ & $\begin{array}{l}-0.0443 \\
(0.478)\end{array}$ & $\begin{array}{c}-0.0794 \\
(0.313)\end{array}$ & $\begin{array}{l}0.0014 \\
(0.984)\end{array}$ & $\begin{array}{l}0.0333 \\
(0.567)\end{array}$ & $\begin{array}{c}-0.1968^{* *} \\
(0.033)\end{array}$ & $\begin{array}{l}0.0126 \\
(0.832)\end{array}$ \\
\hline$\Delta \mathrm{VIX}_{B} \times$ Opacity & $\begin{array}{c}0.0037^{* *} \\
(0.016)\end{array}$ & $\begin{array}{c}0.0289^{* * *} \\
(0.000)\end{array}$ & $\begin{array}{l}0.0276 \\
(0.105)\end{array}$ & $\begin{array}{c}-0.0249 \\
(0.169)\end{array}$ & $\begin{array}{c}0.0805^{\star * *} \\
(0.006)\end{array}$ & $\begin{array}{c}0.0429^{* *} \\
(0.037)\end{array}$ & $\begin{array}{l}0.0465 \\
(0.175)\end{array}$ \\
\hline Observations & 11,214 & 11,879 & 11,040 & 11,931 & 11,931 & 9,155 & 11,931 \\
\hline Number of countries & 19 & 21 & 19 & 21 & 21 & 21 & 21 \\
\hline
\end{tabular}


Table 5 - Global Shocks, Stock Returns and Transparency: Linear Effects

The dependent variable is weekly returns of country MSCI index, winsorized at the top and bottom 0.5 percentile. Table shows the baseline nonlinear effects specification with country and year fixed effects and Driscoll-Kraay standard errors. Capital Flows is the previous three months' average of total flows (purchases plus sales) of foreign securities between U.S. investors and domestic investors (TIC data). Trade is previous twelve months' average of total trade (imports plus exports) originating in each country in the sample (World Bank). Opacit is PWC Opacity Index. Corrup is Transparency International's Country Transparency index. Corpop is the Corporate Opacity Index from the Global Competitiveness Report (World Economic Forum). $\mathrm{W}_{a s}$ is the Accounting Standards factor in the Wilshire Score from Wilshire Associates. Disclosure Djankov, and others' (2008) index of disclosure in periodic filings' component of its Anti-self-dealing index. TGP is the Transparency of Government Policies index by the World Economic Forum. ROSC is a dummy for the publication of a country's first ROSC report. If needed, indices were normalized so as to reflect increasing level of opacity. If needed, indices were normalized so as to reflect increasing level of opacity. $p$-value in parentheses: $* * * \mathrm{p}<0.01$, $* *$ $\mathrm{p}<0.05, * \mathrm{p}<0.1$.

Dependent variable: $\Delta \mathrm{MSCI}_{i, t}$

\begin{tabular}{|c|c|c|c|c|c|c|c|}
\hline Variables & $\begin{array}{c}(1) \\
\text { Opacit }\end{array}$ & $\begin{array}{c}(2) \\
\text { Corrup }\end{array}$ & $\begin{array}{c}(3) \\
\text { Corpop }\end{array}$ & $\begin{array}{l}(4) \\
W_{a s}\end{array}$ & $\begin{array}{c}(5) \\
\text { Disclosure }\end{array}$ & $\begin{array}{c}(6) \\
\text { TGP }\end{array}$ & $\begin{array}{c}(7) \\
\text { ROSC }\end{array}$ \\
\hline$D / Y_{l, t-1}$ & $\begin{array}{c}0.0011^{* *} \\
(0.013)\end{array}$ & $\begin{array}{c}0.0010^{* *} \\
(0.017)\end{array}$ & $\begin{array}{l}0.0007 \\
(0.124)\end{array}$ & $\begin{array}{c}0.0010^{\star *} \\
(0.018)\end{array}$ & $\begin{array}{c}0.0010^{* *} \\
(0.017)\end{array}$ & $\begin{array}{l}0.0010 \\
(0.106)\end{array}$ & $\begin{array}{c}0.0010^{* *} \\
(0.016)\end{array}$ \\
\hline Equity Restrictions & $\begin{array}{l}-0.0013 \\
(0.302)\end{array}$ & $\begin{array}{c}-0.0012 \\
(0.350)\end{array}$ & $\begin{array}{c}-0.0009 \\
(0.532)\end{array}$ & $\begin{array}{l}-0.0013 \\
(0.307)\end{array}$ & $\begin{array}{c}-0.0013 \\
(0.305)\end{array}$ & $\begin{array}{l}-0.0015 \\
(0.286)\end{array}$ & $\begin{array}{c}-0.0012 \\
(0.320)\end{array}$ \\
\hline Banking Crisis & $\begin{array}{c}-0.0204 \\
(0.196)\end{array}$ & $\begin{array}{r}-0.0191 \\
(0.222)\end{array}$ & $\begin{array}{c}-0.0182 \\
(0.243)\end{array}$ & $\begin{array}{r}-0.0201 \\
(0.199)\end{array}$ & $\begin{array}{c}-0.0202 \\
(0.196)\end{array}$ & & $\begin{array}{c}-0.0203 \\
(0.192)\end{array}$ \\
\hline Currency Crisis & $\begin{array}{l}0.0016 \\
(0.805)\end{array}$ & $\begin{array}{l}0.0019 \\
(0.765)\end{array}$ & $\begin{array}{l}0.0025 \\
(0.694)\end{array}$ & $\begin{array}{l}0.0016 \\
(0.805)\end{array}$ & $\begin{array}{l}0.0017 \\
(0.791)\end{array}$ & $\begin{array}{c}-0.0116 \\
(0.243)\end{array}$ & $\begin{array}{l}0.0019 \\
(0.760)\end{array}$ \\
\hline eb & $\begin{array}{l}0.0077 \\
(0.521)\end{array}$ & $\begin{array}{l}0.0069 \\
(0.571)\end{array}$ & $\begin{array}{l}0.0068 \\
(0.578)\end{array}$ & $\begin{array}{l}0.0074 \\
(0.546)\end{array}$ & $\begin{array}{l}0.0075 \\
(0.544)\end{array}$ & & $\begin{array}{l}0.0077 \\
(0.522)\end{array}$ \\
\hline Cap & $\begin{array}{l}0.0001 \\
(0.964)\end{array}$ & $\begin{array}{l}0.0001 \\
(0.962)\end{array}$ & $\begin{array}{c}-0.0002 \\
(0.890)\end{array}$ & $\begin{array}{l}0.0005 \\
(0.819)\end{array}$ & $\begin{array}{l}0.00 \\
0.9\end{array}$ & $\begin{array}{l}0.0017 \\
(0.476)\end{array}$ & $\begin{array}{l}0.0001 \\
(0.967)\end{array}$ \\
\hline Trade & $\begin{array}{l}0.0000 \\
(0.685)\end{array}$ & $\begin{array}{l}0.0000 \\
(0.440)\end{array}$ & & $\begin{array}{l}0.0000 \\
(0.386)\end{array}$ & & $\begin{array}{l}0.0000^{*} \\
(0.097)\end{array}$ & $\begin{array}{l}0.0000 \\
(0.402)\end{array}$ \\
\hline$\Delta \mathrm{VIX} \times$ Capital & $\begin{array}{c}-0.0126^{* *} \\
(0.026)\end{array}$ & $\begin{array}{c}-0.0297^{* * *} \\
(0.000)\end{array}$ & $\begin{array}{c}-0.0236^{\star \star *} \\
(0.000)\end{array}$ & $\begin{array}{c}-0.0620^{* * *} \\
(0.000)\end{array}$ & $\begin{array}{c}-0.0378^{\star \star \star *} \\
(0.000)\end{array}$ & $\begin{array}{c}-0.0282^{* * *} \\
(0.000)\end{array}$ & $\begin{array}{c}-0.0236^{* * *} \\
(0.000)\end{array}$ \\
\hline$\Delta \mathrm{VIX} \times$ Trade & $\begin{array}{l}-0.0000 \\
(0.148)\end{array}$ & $\begin{array}{l}-0.0000 \\
(0.224)\end{array}$ & $\begin{array}{l}0.0000 \\
(0.706)\end{array}$ & $\begin{array}{r}-0.0000 \\
(0.269)\end{array}$ & $\begin{array}{c}-0.0000^{* *} \\
(0.014)\end{array}$ & $\begin{array}{r}-0.0000 \\
(0.172)\end{array}$ & $\begin{array}{r}-0.0000 \\
(0.212)\end{array}$ \\
\hline$\Delta \mathrm{XR}$ & $\begin{array}{c}-0.2707^{\star * \star} \\
(0.000)\end{array}$ & $\begin{array}{c}-0.2756^{* * *} \\
(0.000)\end{array}$ & $\begin{array}{c}-0.2754^{\star * \star} \\
(0.000)\end{array}$ & $\begin{array}{c}-0.2657^{\star \star \star} \\
(0.000)\end{array}$ & $\begin{array}{c}-0.2708^{* * *} \\
(0.000)\end{array}$ & $\begin{array}{c}-0.2604^{* * *} \\
(0.000)\end{array}$ & $\begin{array}{c}-0.2754^{* * *} \\
(0.000)\end{array}$ \\
\hline$\Delta \mathrm{M}$ & $\begin{array}{l}0.2076 \\
(0.191)\end{array}$ & $\begin{array}{l}0.1999 \\
(0.177)\end{array}$ & $\begin{array}{l}0.2059 \\
(0.188)\end{array}$ & $\begin{array}{l}0.1683 \\
(0.250)\end{array}$ & $\begin{array}{l}0.18 \\
(0.1\end{array}$ & $\begin{array}{l}0.0409 \\
(0.853)\end{array}$ & $\begin{array}{l}0.1891 \\
(0.195)\end{array}$ \\
\hline$\Delta \mathrm{MS}$ & $\begin{array}{c}0.0008^{\star *} \\
(0.025)\end{array}$ & $\begin{array}{c}0.0008^{* *} \\
(0.030)\end{array}$ & $\begin{array}{c}0.0008^{* *} \\
(0.027)\end{array}$ & $\begin{array}{c}0.0008^{* *} \\
(0.022)\end{array}$ & $\begin{array}{c}0.0008^{* *} \\
(0.026)\end{array}$ & $\begin{array}{c}0.0010^{* *} \\
(0.026)\end{array}$ & $\begin{array}{c}0.0008^{* *} \\
(0.026)\end{array}$ \\
\hline$\Delta \mathrm{VIX}$ & $\begin{array}{l}0.0160 \\
(0.618)\end{array}$ & $\begin{array}{l}0.0196 \\
(0.489)\end{array}$ & $\begin{array}{l}0.0360 \\
(0.253)\end{array}$ & $\begin{array}{c}-0.0364 \\
(0.301)\end{array}$ & $\begin{array}{l}0.0365 \\
(0.221)\end{array}$ & $\begin{array}{c}0.0745^{\star *} \\
(0.034)\end{array}$ & $\begin{array}{c}-0.0032 \\
(0.912)\end{array}$ \\
\hline$\Delta \mathrm{VIX} \times t$ & $\begin{array}{l}-0.0000 \\
(0.611)\end{array}$ & $\begin{array}{l}-0.0000 \\
(0.723)\end{array}$ & $\begin{array}{l}-0.0000 \\
(0.763)\end{array}$ & $\begin{array}{l}0.0000 \\
(0.980)\end{array}$ & $\begin{array}{c}-0.0000 \\
(0.687)\end{array}$ & $\begin{array}{l}-0.0001 \\
(0.345)\end{array}$ & $\begin{array}{c}-0.0000 \\
(0.782)\end{array}$ \\
\hline Opacity & $\begin{array}{l}-0.0000 \\
(0.979)\end{array}$ & 0.0007 & $\begin{array}{l}0.0001 \\
(0.939)\end{array}$ & $\begin{array}{l}0.0005 \\
(0.589)\end{array}$ & & $\begin{array}{c}0.0028^{* *} \\
(0.028)\end{array}$ & $\begin{array}{c}-0.0004 \\
(0.821)\end{array}$ \\
\hline$\Delta \mathrm{VIX} \times \mathrm{Opa}$ & $\begin{array}{c}-0.0004 \\
(0.189)\end{array}$ & $\begin{array}{c}-0.0030^{* *} \\
(0.023)\end{array}$ & $\begin{array}{c}-0.0129^{* * \star} \\
(0.003)\end{array}$ & $\begin{array}{c}-0.0211^{\star * *} \\
(0.007)\end{array}$ & $\begin{array}{c}-0.0625^{* * *} \\
(0.000)\end{array}$ & $\begin{array}{c}-0.0162^{* * *} \\
(0.000)\end{array}$ & $\begin{array}{l}0.0033 \\
(0.679)\end{array}$ \\
\hline Obs & 15,242 & 16,746 & 15,502 & 15,502 & 16,850 & 12,846 & 16,850 \\
\hline Number of countries & 23 & 25 & 23 & 23 & 25 & 25 & 25 \\
\hline
\end{tabular}


Table 6 - Global Shocks, Stock Returns, and Transparency: Asymmetric Effects

The dependent variable is weekly returns of country MSCI index, winsorized at the top and bottom 0.5 percentile. Table shows the asymmetric effects specification with country and year fixed effects and Driscoll-Kraay standard errors. $\Delta$ VIX $_{G}$ and $\triangle \mathrm{VIX}_{B}$ stand for good (decrease) and bad (increase) volatility shocks (measured by VIX). Capital Flows is the previous three months' average of total flows (purchases plus sales) of foreign securities between U.S. investors and domestic investors (TIC data). Trade is previous twelve months' average of total trade (imports plus exports) originating in each country in the sample (World Bank). Opacit is PWC Opacity Index. Corrup is Transparency International's Country Transparency index. Corpop is the Corporate Opacity Index from the Global Competitiveness Report (World Economic Forum). $\mathrm{W}_{a s}$ is the Accounting Standards factor in the Wilshire Score from Wilshire Associates. Disclosure is Djankov, and others' (2008) index of disclosure in periodic filings' component of its Anti-self-dealing index. TGP is the Transparency of Government Policies index by the World Economic Forum. ROSC is a dummy for the publication of a country's first ROSC report. If needed, indices were normalized so as to reflect increasing level of opacity. If needed, indices were normalized so as to reflect increasing level of opacity. $p$-value in parentheses: *** $\mathrm{p}<0.01, * * \mathrm{p}<0.05, * \mathrm{p}<0.1$.

Dependent variable: $\Delta \mathrm{MSCI}_{i, t}$

\begin{tabular}{|c|c|c|c|c|c|c|c|}
\hline Variables & $\begin{array}{c}(1) \\
\text { Opacit }\end{array}$ & $\begin{array}{c}(2) \\
\text { Corrup }\end{array}$ & $\begin{array}{c}(3) \\
\text { Corpop }\end{array}$ & $\begin{array}{l}\text { (4) } \\
\mathrm{W}_{a s}\end{array}$ & $\begin{array}{c}(5) \\
\text { Disclosure }\end{array}$ & $\begin{array}{c}(6) \\
\text { TGP }\end{array}$ & $\begin{array}{c}(7) \\
\text { ROSC }\end{array}$ \\
\hline$D / Y_{l, t-1}$ & & & & & & & \\
\hline Equity Restrictions & $\begin{array}{c}-0.0012 \\
(0.356)\end{array}$ & $\begin{array}{r}-0.0009 \\
(0.469)\end{array}$ & $\begin{array}{l}-0.0006 \\
(0.656)\end{array}$ & & & $\begin{array}{l}-0.0 \\
(0.5\end{array}$ & \\
\hline Banking Crisis & $\begin{array}{r}-0.0201 \\
(0.195)\end{array}$ & $\begin{array}{l}-0.0189 \\
(0.220)\end{array}$ & $\begin{array}{c}-0.0180 \\
(0.243)\end{array}$ & $\begin{array}{c}-0.0198 \\
(0.200)\end{array}$ & $\begin{array}{c}-0.0200 \\
(0.195)\end{array}$ & & $\begin{array}{c}-0.0202 \\
(0.189)\end{array}$ \\
\hline Currency Crisis & $\begin{array}{l}0.0014 \\
(0.819)\end{array}$ & $\begin{array}{l}0.0017 \\
(0.787)\end{array}$ & $\begin{array}{l}0.0023 \\
(0.720)\end{array}$ & & $\begin{array}{l}0.0014 \\
(0.821)\end{array}$ & $\begin{array}{l}-0.0 \\
(0.2\end{array}$ & \\
\hline Debt Crisis & $\begin{array}{l}0.00 \\
(0.5\end{array}$ & $\begin{array}{l}0.00 \\
(0.5\end{array}$ & $\begin{array}{l}0.00 \\
(0.5\end{array}$ & & $\begin{array}{l}0.0 \\
(0.5\end{array}$ & & \\
\hline Capital F & $\begin{array}{l}0.00 \\
(0.8\end{array}$ & $\begin{array}{l}0.0 \\
(0.9\end{array}$ & & & & & \\
\hline Trade & $\begin{array}{l}0.00 \\
(0.8\end{array}$ & $\begin{array}{l}0.00 \\
(0.6\end{array}$ & & & $\begin{array}{l}0.0 \\
(0.6\end{array}$ & $\begin{array}{l}0.0000 \\
(0.165)\end{array}$ & \\
\hline $\mathrm{I} X \times C$ & $\begin{array}{c}-0.0127^{* *} \\
(0.024)\end{array}$ & $\begin{array}{r}-0.029 \\
(0.00\end{array}$ & $\begin{array}{c}-0.0234^{* * *} \\
(0.000)\end{array}$ & $\begin{array}{r}-0.06 \\
(0.0\end{array}$ & $\begin{array}{r}-0.03 \\
(0.0\end{array}$ & $\begin{array}{c}-0.0283^{* * *} \\
(0.000)\end{array}$ & $\begin{array}{c}-0.0233^{* * *} \\
(0.000)\end{array}$ \\
\hline VIX xTrade & $\begin{array}{c}-0.0000 \\
(0.146)\end{array}$ & $\begin{array}{l}-0.00 \\
(0.2\end{array}$ & $\begin{array}{l}0.00 \\
(0.7\end{array}$ & -0.0 & $\begin{array}{r}-0.00 \\
(0.0\end{array}$ & $\begin{array}{l}-0 . \\
(0 .\end{array}$ & $\begin{array}{l}-0.0 \\
(0.1\end{array}$ \\
\hline$\Delta \mathrm{XR}$ & $\begin{array}{c}-0.2642^{* * *} \\
(0.000)\end{array}$ & $\begin{array}{c}-0.2689^{* * *} \\
(0.000)\end{array}$ & $\begin{array}{c}-0.2685^{\star * *} \\
(0.000)\end{array}$ & $\begin{array}{c}-0.2589^{* * *} \\
(0.000)\end{array}$ & $\begin{array}{c}-0.2637^{* * *} \\
(0.000)\end{array}$ & $\begin{array}{c}-0.2567^{* * *} \\
(0.000)\end{array}$ & $\begin{array}{c}-0.2674^{* * *} \\
(0.000)\end{array}$ \\
\hline MSCI US & $\begin{array}{l}0.2365 \\
(0.127)\end{array}$ & $\begin{array}{l}0.2059 \\
(0.158)\end{array}$ & $\begin{array}{l}0.2123 \\
(0.169)\end{array}$ & 0.1 & & $\begin{array}{l}10 \\
9)\end{array}$ & 2) \\
\hline$\Delta \mathrm{MSCl} \_\mathrm{US} \times t$ & $\begin{array}{c}0.0008^{* *} \\
(0.024)\end{array}$ & $\begin{array}{c}0.0008^{* *} \\
(0.022)\end{array}$ & $\begin{array}{c}0.0009^{* *} \\
(0.020)\end{array}$ & $\begin{array}{c}0.0008^{* *} \\
(0.016)\end{array}$ & $\begin{array}{r}0.00 \\
(0.0\end{array}$ & $\begin{array}{c}0.0011^{* *} \\
(0.020)\end{array}$ & $\begin{array}{c}0.0008^{* *} \\
(0.021)\end{array}$ \\
\hline $\mathrm{VIX} \times t$ & $\begin{array}{l}-0.00 \\
(0.70\end{array}$ & $\begin{array}{l}-0.00 \\
(0.9\end{array}$ & $\begin{array}{l}-0.0 \\
(0.9\end{array}$ & $\begin{array}{l}0.0000 \\
(0.801)\end{array}$ & $\begin{array}{l}-0.0000 \\
(0.883)\end{array}$ & $\begin{array}{l}-0.0 \\
10 .\end{array}$ & $\begin{array}{l}-0.0 \\
(0.9\end{array}$ \\
\hline Opa & $\begin{array}{l}0.0001 \\
(0.304)\end{array}$ & $\begin{array}{l}0.0011 \\
(0.241)\end{array}$ & $\begin{array}{l}0.0011 \\
(0.147)\end{array}$ & $\begin{array}{l}0.0006 \\
(0.629)\end{array}$ & & $\begin{array}{c}0.0035^{\star * *} \\
(0.007)\end{array}$ & $\begin{array}{l}0.0015 \\
(0.533)\end{array}$ \\
\hline$\Delta \mathrm{VIX}$ & $\begin{array}{r}-0.0 \\
(0.8\end{array}$ & 0.0 & 0.0 & 1) & $\begin{array}{r}0.07 \\
(0 .\end{array}$ & $\begin{array}{l}5 \\
4)\end{array}$ & 9 \\
\hline$\Delta \mathrm{VIX}_{G \times} \times$ Opacity & $\begin{array}{l}0.0013 \\
(0.128)\end{array}$ & $\begin{array}{c}0.0043^{*} \\
(0.063)\end{array}$ & $\begin{array}{c}-0.0013 \\
(0.831)\end{array}$ & $\begin{array}{c}-0.0238^{*} \\
(0.083)\end{array}$ & $\begin{array}{c}-0.0457^{* * *} \\
(0.007)\end{array}$ & $\begin{array}{c}-0.0016 \\
(0.845)\end{array}$ & $\begin{array}{l}0.0354^{*} \\
(0.069)\end{array}$ \\
\hline$\Delta \mathrm{VIX}_{B}$ & $\begin{array}{l}0.0315 \\
(0.378)\end{array}$ & $\begin{array}{l}0.01 \\
(0.5\end{array}$ & $\begin{array}{l}0.0290 \\
(0.367)\end{array}$ & $\begin{array}{c}-0.0605 \\
(0.111)\end{array}$ & $\begin{array}{l}0.01 \\
(0.6\end{array}$ & $\begin{array}{c}0.0742^{\star \star} \\
(0.041)\end{array}$ & $\begin{array}{l}-0.0243 \\
(0.436)\end{array}$ \\
\hline$\Delta \mathrm{VIX}_{B} \times \mathrm{Opac}$ & $\begin{array}{c}-0.0013^{* *} \\
(0.014)\end{array}$ & $\begin{array}{c}-0.0071^{* * *} \\
(0.000)\end{array}$ & $\begin{array}{c}-0.0192^{* * *} \\
(0.000)\end{array}$ & $\begin{array}{c}-0.0193^{*} \\
(0.050)\end{array}$ & $\begin{array}{c}-0.0719^{* * *} \\
(0.000)\end{array}$ & $\begin{array}{c}-0.0244^{* * *} \\
(0.000)\end{array}$ & $\begin{array}{c}-0.0140 \\
(0.303)\end{array}$ \\
\hline & 15,242 & 16,746 & 15,502 & 15,502 & 16,850 & 12,846 & 16,850 \\
\hline & 23 & $-C$ & 23 & 23 & $C$ & 25 & 25 \\
\hline
\end{tabular}


Table 7 - Global Shocks, Stock Returns, Transparency, and Country Risk Ratings

The dependent variable is weekly returns of country MSCI index, winsorized at the top and bottom 0.5 percentile. Table shows the baseline nonlinear effects specification with country and year fixed effects and Driscoll-Kraay standard errors. Capital Flows is the previous three months' average of total flows (purchases plus sales) of foreign securities between U.S. investors and domestic investors (TIC data). Trade is previous twelve months' average of total trade (imports plus exports) originating in each country in the sample (World Bank). Opacit is PWC Opacity Index. Corrup is Transparency International's Country Transparency index. Corpop is the Corporate Opacity Index from the Global Competitiveness Report (World Economic Forum). $\mathrm{W}_{a s}$ is the Accounting Standards factor in the Wilshire Score from Wilshire Associates. Disclosure Djankov, and others' (2008) index of disclosure in periodic filings' component of its Anti-self-dealing index. TGP is the Transparency of Government Policies index by the World Economic Forum. ROSC is a dummy for the publication of a country's first ROSC report. CRR is ICRG's Composite Country Risk. If needed, indices were normalized so as to reflect increasing level of opacity. If needed, indices were normalized so as to reflect increasing level of opacity. $p$ value in parentheses: $* * * \mathrm{p}<0.01, * * \mathrm{p}<0.05, * \mathrm{p}<0.1$.

Dependent variable: $\Delta \mathrm{MSCI}_{i, t}$

\begin{tabular}{|c|c|c|c|c|c|c|c|}
\hline Variables & $\begin{array}{c}(1) \\
\text { Opacit }\end{array}$ & $\begin{array}{c}(2) \\
\text { Corrup } \\
\end{array}$ & $\begin{array}{c}(3) \\
\text { Corpop } \\
\end{array}$ & $\begin{array}{l}(4) \\
W_{a s}\end{array}$ & $\begin{array}{c}(5) \\
\text { Disclosure }\end{array}$ & $\begin{array}{c}\text { (6) } \\
\text { TGP }\end{array}$ & $\begin{array}{c}(7) \\
\text { ROSC } \\
\end{array}$ \\
\hline$D / Y_{l, t-1}$ & $\begin{array}{c}0.0011^{* *} \\
(0.011)\end{array}$ & $\begin{array}{c}0.0010^{* *} \\
(0.014)\end{array}$ & $\begin{array}{l}0.0007 \\
(0.132)\end{array}$ & $\begin{array}{c}0.0011^{* *} \\
(0.014)\end{array}$ & $\begin{array}{l}0.00 \\
(0 .\end{array}$ & $\begin{array}{l}0.0011^{*} \\
(0.065)\end{array}$ & $\begin{array}{c}0.0010^{* *} \\
(0.014)\end{array}$ \\
\hline Equity Restrictions & $\begin{array}{r}-0.0013 \\
(0.302)\end{array}$ & $\begin{array}{r}-0.0011 \\
(0.378)\end{array}$ & $\begin{array}{c}-0.0007 \\
(0.604)\end{array}$ & $\begin{array}{c}-0.0012 \\
(0.342)\end{array}$ & $\begin{array}{c}-0.0012 \\
(0.342)\end{array}$ & $\begin{array}{c}-0.0014 \\
(0.305)\end{array}$ & $\begin{array}{r}-0.0011 \\
(0.363)\end{array}$ \\
\hline 3anking Crisis & $\begin{array}{r}-0.0192 \\
(0.217)\end{array}$ & $\begin{array}{c}-0.0187 \\
(0.221)\end{array}$ & $\begin{array}{c}-0.0169 \\
(0.266)\end{array}$ & $\begin{array}{c}-0.0203 \\
(0.186)\end{array}$ & $\begin{array}{l}-0.0 \\
(0.1\end{array}$ & & $\begin{array}{l}-0.0195 \\
(0.205)\end{array}$ \\
\hline Currency Crisis & $\begin{array}{l}0.0003 \\
(0.961)\end{array}$ & $\begin{array}{l}0.0011 \\
(0.853)\end{array}$ & $\begin{array}{l}0.0014 \\
(0.824)\end{array}$ & $\begin{array}{l}0.0013 \\
(0.831)\end{array}$ & $\begin{array}{l}0.0010 \\
(0.874)\end{array}$ & $\begin{array}{c}-0.0120 \\
(0.245)\end{array}$ & $\begin{array}{l}0.0010 \\
(0.876)\end{array}$ \\
\hline Debt Crisis & $\begin{array}{l}0.0066 \\
(0.582)\end{array}$ & $\begin{array}{l}0.0063 \\
(0.587)\end{array}$ & $\begin{array}{l}0.0055 \\
(0.635)\end{array}$ & $\begin{array}{l}0.0075 \\
(0.526)\end{array}$ & $\begin{array}{l}0.00 \\
0.5\end{array}$ & & $\begin{array}{l}0.0067 \\
(0.563)\end{array}$ \\
\hline Capital & $\begin{array}{r}-0.0001 \\
(0.933)\end{array}$ & $\begin{array}{r}-0.0001 \\
(0.970)\end{array}$ & $\begin{array}{c}-0.0005 \\
(0.781)\end{array}$ & $\begin{array}{l}0.0004 \\
(0.831)\end{array}$ & $\begin{array}{r}-0.0001 \\
(0.950)\end{array}$ & $\begin{array}{l}0.0015 \\
(0.546)\end{array}$ & $\begin{array}{r}-0.0001 \\
(0.931)\end{array}$ \\
\hline Trade & $\begin{array}{l}0.0000 \\
(0.628)\end{array}$ & $\begin{array}{l}0.0000 \\
(0.469)\end{array}$ & $\begin{array}{l}0.0000 \\
(0.547)\end{array}$ & $\begin{array}{l}0.0000 \\
(0.388)\end{array}$ & & $\begin{array}{l}0.0000 \\
(0.116)\end{array}$ & $\begin{array}{l}0.0000 \\
(0.443)\end{array}$ \\
\hline$\Delta \mathrm{VIX}$ & $\begin{array}{r}-0.0041 \\
(0.474)\end{array}$ & $\begin{array}{c}-0.0280^{* * *} \\
(0.000)\end{array}$ & $\begin{array}{c}-0.0216^{* * *} \\
(0.001)\end{array}$ & $\begin{array}{c}-0.0637^{* * *} \\
(0.000)\end{array}$ & $\begin{array}{c}-0.0284^{* * *} \\
(0.000)\end{array}$ & $\begin{array}{c}-0.0156^{* * *} \\
(0.006)\end{array}$ & $\begin{array}{c}-0.0169^{* * *} \\
(0.006)\end{array}$ \\
\hline V & $\begin{array}{r}-0.0000 \\
(0.284)\end{array}$ & $\begin{array}{r}-0.0000 \\
(0.538)\end{array}$ & $\begin{array}{l}0.0000 \\
(0.637)\end{array}$ & $\begin{array}{l}0.0000 \\
(0.873)\end{array}$ & $\begin{array}{r}-0.0 \\
(0.0\end{array}$ & $\begin{array}{c}-0.0000 \\
(0.148)\end{array}$ & $\begin{array}{l}-0.0000 \\
(0.460)\end{array}$ \\
\hline$\Delta \mathrm{XF}$ & $\begin{array}{c}-0.2731^{\star * *} \\
(0.000)\end{array}$ & $\begin{array}{c}-0.2782^{* * *} \\
(0.000)\end{array}$ & $\begin{array}{c}-0.2762^{\star * \star} \\
(0.000)\end{array}$ & $\begin{array}{c}-0.2669^{* * *} \\
(0.000)\end{array}$ & $\begin{array}{c}-0.2725^{* * *} \\
(0.000)\end{array}$ & $\begin{array}{c}-0.2612^{* * *} \\
(0.000)\end{array}$ & $\begin{array}{c}-0.2768^{* * *} \\
(0.000)\end{array}$ \\
\hline$\triangle \mathrm{MSCl}$ US & $\begin{array}{l}0.2085 \\
(0.189)\end{array}$ & $\begin{array}{l}0.2046 \\
(0.169)\end{array}$ & $\begin{array}{l}0.2076 \\
(0.186)\end{array}$ & $\begin{array}{l}0.1746 \\
(0.235)\end{array}$ & $\begin{array}{l}0.1926 \\
(0.189)\end{array}$ & $\begin{array}{l}0.0636 \\
(0.773)\end{array}$ & $\begin{array}{l}0.1915 \\
(0.191)\end{array}$ \\
\hline$\Delta \mathrm{MSCl}$ US $\times t$ & $\begin{array}{c}0.0008^{* *} \\
(0.024)\end{array}$ & $\begin{array}{c}0.0008^{* *} \\
(0.030)\end{array}$ & $\begin{array}{c}0.0008^{* *} \\
(0.027)\end{array}$ & $\begin{array}{c}0.0008^{* *} \\
(0.022)\end{array}$ & $\begin{array}{c}0.0008^{* *} \\
(0.026)\end{array}$ & $\begin{array}{c}0.0010^{* *} \\
(0.030)\end{array}$ & $\begin{array}{c}0.0008^{* *} \\
(0.026)\end{array}$ \\
\hline$\Delta \mathrm{VIX}$ & $\begin{array}{c}0.2292^{* * *} \\
(0.001)\end{array}$ & $\begin{array}{c}0.2408^{* * *} \\
(0.001)\end{array}$ & $\begin{array}{l}0.0847 \\
(0.107)\end{array}$ & $\begin{array}{c}0.1584^{* * *} \\
(0.005)\end{array}$ & $\begin{array}{c}0.1674^{* * *} \\
(0.002)\end{array}$ & $\begin{array}{c}0.3818^{* * *} \\
(0.000)\end{array}$ & $\begin{array}{c}0.0819^{*} \\
(0.075)\end{array}$ \\
\hline$\Delta \mathrm{VIX} \times t$ & $\begin{array}{r}-0.0000 \\
(0.426)\end{array}$ & $\begin{array}{r}-0.0000 \\
(0.886)\end{array}$ & $\begin{array}{c}-0.0000 \\
(0.796)\end{array}$ & $\begin{array}{l}0.0000 \\
(0.688)\end{array}$ & $\begin{array}{r}-0.0000 \\
(0.818)\end{array}$ & $\begin{array}{r}-0.0001 \\
(0.203)\end{array}$ & $\begin{array}{l}-0.0000 \\
(0.820)\end{array}$ \\
\hline CCR & $\begin{array}{r}-0.0001 \\
(0.603)\end{array}$ & $\begin{array}{r}-0.0000 \\
(0.870)\end{array}$ & $\begin{array}{r}-0.0001 \\
(0.633)\end{array}$ & $\begin{array}{l}0.0000 \\
(0.917)\end{array}$ & $\begin{array}{r}-0.0000 \\
(0.859)\end{array}$ & $\begin{array}{l}0.0000 \\
(0.788)\end{array}$ & $\begin{array}{r}-0.0001 \\
(0.646)\end{array}$ \\
\hline$\Delta \mathrm{VIX}$ & $\begin{array}{c}-0.0025^{\star * *} \\
(0.001)\end{array}$ & $\begin{array}{c}-0.0026^{* * *} \\
(0.002)\end{array}$ & $\begin{array}{c}-0.0006 \\
(0.227)\end{array}$ & $\begin{array}{c}-0.0030^{* * *} \\
(0.000)\end{array}$ & $\begin{array}{c}-0.0019^{* * *} \\
(0.001)\end{array}$ & $\begin{array}{c}-0.0036^{* * *} \\
(0.000)\end{array}$ & $\begin{array}{c}-0.0012^{* *} \\
(0.018)\end{array}$ \\
\hline Op & $\begin{array}{r}-0.0000 \\
(0.847)\end{array}$ & $\begin{array}{l}0.0007 \\
(0.469)\end{array}$ & $\begin{array}{l}0.0020 \\
(0.614)\end{array}$ & $\begin{array}{l}0.0006 \\
(0.560)\end{array}$ & & $\begin{array}{c}0.0027^{\star *} \\
(0.032)\end{array}$ & $\begin{array}{l}-0.0007 \\
(0.699)\end{array}$ \\
\hline$\Delta \mathrm{V}$ & $\begin{array}{c}-0.0011^{\star * *} \\
(0.007)\end{array}$ & $\begin{array}{c}-0.0097^{* * *} \\
(0.000)\end{array}$ & $\begin{array}{c}-0.0147^{\star * \star} \\
(0.002)\end{array}$ & $\begin{array}{c}-0.0257^{* * *} \\
(0.002)\end{array}$ & $\begin{array}{c}-0.0697^{* * *} \\
(0.000)\end{array}$ & $\begin{array}{c}-0.0289^{* * *} \\
(0.000)\end{array}$ & $\begin{array}{l}0.0005 \\
(0.948)\end{array}$ \\
\hline 0 & 15,196 & 16,696 & 15,456 & 15,456 & 16,800 & 12,796 & 16,800 \\
\hline Jun & 23 & 25 & 23 & 23 & 25 & 25 & 25 \\
\hline
\end{tabular}


Table 8 - Global Shocks, Stock Returns, Transparency, and Market Liquidity

The dependent variable is weekly returns of country MSCI index, winsorized at the top and bottom 0.5 percentile. Table shows the baseline nonlinear effects specification with country and year fixed effects and Driscoll-Kraay standard errors. Capital Flows is the previous three months' average of total flows (purchases plus sales) of foreign securities between U.S. investors and domestic investors (TIC data). Trade is previous twelve months' average of total trade (imports plus exports) originating in each country in the sample (World Bank). Opacit is PWC Opacity Index. Corrup is Transparency International's Country Transparency index. Corpop is the Corporate Opacity Index from the Global Competitiveness Report (World Economic Forum). $\mathrm{W}_{a s}$ is the Accounting Standards factor in the Wilshire Score from Wilshire Associates. Disclosure Djankov, and others' (2008) index of disclosure in periodic filings' component of its Anti-self-dealing index. TGP is the Transparency of Government Policies index by the World Economic Forum. ROSC is a dummy for the publication of a country's first ROSC report. Illiquidity is Amihud's (2002) measure of market illiquidity. If needed, indices were normalized so as to reflect increasing level of opacity. If needed, indices were normalized so as to reflect increasing level of opacity. $p$-value in parentheses: $* * * \mathrm{p}<0.01, * * \mathrm{p}<0.05, * \mathrm{p}<0.1$.

Dependent variable: $\Delta \mathrm{MSCI}_{i, t}$

\begin{tabular}{|c|c|c|c|c|c|c|c|}
\hline Variables & $\begin{array}{c}(1) \\
\text { Opacit }\end{array}$ & $\begin{array}{c}(2) \\
\text { Corrup } \\
\end{array}$ & $\begin{array}{c}\text { (3) } \\
\text { Corpop }\end{array}$ & $\begin{array}{l}(4) \\
W_{s r}\end{array}$ & $\begin{array}{c}(5) \\
\text { Disclosure }\end{array}$ & $\begin{array}{c}6) \\
\text { TGP }\end{array}$ & $\begin{array}{c}(7) \\
\text { ROSC } \\
\end{array}$ \\
\hline$D / Y_{l, t-1}$ & $\begin{array}{c}0.0011^{* *} \\
(0.013)\end{array}$ & $\begin{array}{c}0.0011^{* *} \\
(0.014)\end{array}$ & $\begin{array}{l}0.0008 \\
(0.109)\end{array}$ & $\begin{array}{c}0.0011^{* *} \\
(0.015)\end{array}$ & $\begin{array}{c}0.0011^{* *} \\
(0.015)\end{array}$ & $\begin{array}{l}0.0010^{*} \\
(0.092)\end{array}$ & $\begin{array}{c}0.0011^{* *} \\
(0.013)\end{array}$ \\
\hline Equity Restrictions & $\begin{array}{c}-0.0012 \\
(0.334)\end{array}$ & $\begin{array}{r}-0.0011 \\
(0.372)\end{array}$ & $\begin{array}{l}-0.0008 \\
(0.539)\end{array}$ & $\begin{array}{c}-0.0013 \\
(0.317)\end{array}$ & $\begin{array}{c}-0.0013 \\
(0.310)\end{array}$ & $\begin{array}{r}-0.0015 \\
(0.278)\end{array}$ & $\begin{array}{c}-0.0012 \\
(0.325)\end{array}$ \\
\hline Banking Crisis & $\begin{array}{c}-0.0202 \\
(0.200)\end{array}$ & $\begin{array}{l}-0.0187 \\
(0.230)\end{array}$ & $\begin{array}{l}-0.0185 \\
(0.234)\end{array}$ & $\begin{array}{c}-0.0202 \\
(0.197)\end{array}$ & $\begin{array}{c}-0.0203 \\
(0.194)\end{array}$ & & $\begin{array}{c}-0.0203 \\
(0.192)\end{array}$ \\
\hline Currency Crisis & $\begin{array}{l}0.0021 \\
(0.740)\end{array}$ & $\begin{array}{l}0.0024 \\
(0.713)\end{array}$ & $\begin{array}{l}0.0027 \\
(0.675)\end{array}$ & $\begin{array}{l}0.0020 \\
(0.754)\end{array}$ & $\begin{array}{l}0.0021 \\
(0.743)\end{array}$ & $\begin{array}{r}-0.0115 \\
(0.248)\end{array}$ & $\begin{array}{l}0.0023 \\
(0.719)\end{array}$ \\
\hline Debt Crisis & $\begin{array}{l}0.0078 \\
(0.516)\end{array}$ & $\begin{array}{l}0.0072 \\
(0.559)\end{array}$ & $\begin{array}{l}0.0072 \\
(0.557)\end{array}$ & $\begin{array}{l}0.0079 \\
(0.525)\end{array}$ & $\begin{array}{l}0.0079 \\
(0.523)\end{array}$ & & $\begin{array}{l}0.0080 \\
(0.507)\end{array}$ \\
\hline Capital Flows & $\begin{array}{l}0.0003 \\
(0.843)\end{array}$ & $\begin{array}{l}0.0003 \\
(0.832)\end{array}$ & $\begin{array}{l}0.0000 \\
(0.996)\end{array}$ & $\begin{array}{l}0.0008 \\
(0.698)\end{array}$ & $\begin{array}{l}0.0004 \\
(0.818)\end{array}$ & $\begin{array}{l}0.0017 \\
(0.474)\end{array}$ & $\begin{array}{l}0.0003 \\
(0.847)\end{array}$ \\
\hline Trade & $\begin{array}{l}0.0000 \\
(0.774)\end{array}$ & $\begin{array}{l}0.0000 \\
(0.653)\end{array}$ & $\begin{array}{l}0.0000 \\
(0.715)\end{array}$ & $\begin{array}{l}0.0000 \\
(0.590)\end{array}$ & $\begin{array}{l}0.0000 \\
(0.686)\end{array}$ & $\begin{array}{l}0.0000 \\
(0.177)\end{array}$ & $\begin{array}{l}0.0000 \\
(0.620)\end{array}$ \\
\hline$\Delta \mathrm{VIX} \times$ Capital Flows & $\begin{array}{c}-0.0118^{* *} \\
(0.037)\end{array}$ & $\begin{array}{c}-0.0173^{* * *} \\
(0.003)\end{array}$ & $\begin{array}{c}-0.0096^{*} \\
(0.092)\end{array}$ & $\begin{array}{c}-0.0494^{* * *} \\
(0.000)\end{array}$ & $\begin{array}{c}-0.0311^{* * *} \\
(0.000)\end{array}$ & $\begin{array}{c}-0.0215^{\star * *} \\
(0.001)\end{array}$ & $\begin{array}{c}-0.0151^{* * *} \\
(0.003)\end{array}$ \\
\hline$\Delta \mathrm{VIX} \times$ Trade & $\begin{array}{r}-0.0000 \\
(0.183)\end{array}$ & $\begin{array}{r}-0.0000 \\
(0.230)\end{array}$ & $\begin{array}{l}0.0000 \\
(0.635)\end{array}$ & $\begin{array}{r}-0.0000 \\
(0.226)\end{array}$ & $\begin{array}{c}-0.0000^{* * *} \\
(0.004)\end{array}$ & $\begin{array}{r}-0.0000 \\
(0.173)\end{array}$ & $\begin{array}{l}-0.0000 \\
(0.162)\end{array}$ \\
\hline$\triangle \mathrm{XRATE}$ & $\begin{array}{c}-0.2718^{* * *} \\
(0.000)\end{array}$ & $\begin{array}{c}-0.2735^{\star * *} \\
(0.000)\end{array}$ & $\begin{array}{c}-0.2721^{* * *} \\
(0.000)\end{array}$ & $\begin{array}{c}-0.2648^{* * *} \\
(0.000)\end{array}$ & $\begin{array}{c}-0.2672^{\star * *} \\
(0.000)\end{array}$ & $\begin{array}{c}-0.2572^{* * *} \\
(0.000)\end{array}$ & $\begin{array}{c}-0.2732^{* * *} \\
(0.000)\end{array}$ \\
\hline$\triangle \mathrm{MSCl}$ US & $\begin{array}{l}0.2141 \\
(0.178)\end{array}$ & $\begin{array}{l}0.2117 \\
(0.165)\end{array}$ & $\begin{array}{l}0.2175 \\
(0.178)\end{array}$ & $\begin{array}{l}0.1781 \\
(0.238)\end{array}$ & $\begin{array}{l}0.2000 \\
(0.182)\end{array}$ & $\begin{array}{l}0.0500 \\
(0.823)\end{array}$ & $\begin{array}{l}0.2002 \\
(0.182)\end{array}$ \\
\hline$\Delta \mathrm{MSCl} \_\mathrm{US} \times t$ & $\begin{array}{c}0.0008^{* *} \\
(0.027)\end{array}$ & $\begin{array}{c}0.0008^{* *} \\
(0.030)\end{array}$ & $\begin{array}{c}0.0008^{* *} \\
(0.026)\end{array}$ & $\begin{array}{c}0.0008^{* *} \\
(0.022)\end{array}$ & $\begin{array}{c}0.0008^{* *} \\
(0.026)\end{array}$ & $\begin{array}{c}0.0011^{* *} \\
(0.024)\end{array}$ & $\begin{array}{c}0.0008^{* *} \\
(0.026)\end{array}$ \\
\hline$\Delta \mathrm{VIX}$ & $\begin{array}{l}0.0146 \\
(0.652)\end{array}$ & $\begin{array}{l}0.0018 \\
(0.951)\end{array}$ & $\begin{array}{l}0.0133 \\
(0.683)\end{array}$ & $\begin{array}{c}-0.0335 \\
(0.345)\end{array}$ & $\begin{array}{l}0.0400 \\
(0.196)\end{array}$ & $\begin{array}{c}0.0687^{*} \\
(0.053)\end{array}$ & $\begin{array}{c}-0.0089 \\
(0.772)\end{array}$ \\
\hline$\Delta \mathrm{VIX} \times t$ & $\begin{array}{c}-0.0000 \\
(0.594)\end{array}$ & $\begin{array}{c}-0.0000 \\
(0.713)\end{array}$ & $\begin{array}{c}-0.0000 \\
(0.727)\end{array}$ & $\begin{array}{r}-0.0000 \\
(0.951)\end{array}$ & $\begin{array}{c}-0.0000 \\
(0.660)\end{array}$ & $\begin{array}{r}-0.0001 \\
(0.375)\end{array}$ & $\begin{array}{c}-0.0000 \\
(0.796)\end{array}$ \\
\hline Illiquidity & $\begin{array}{c}-5.3325 \\
(0.353)\end{array}$ & $\begin{array}{r}-5.0212 \\
(0.378)\end{array}$ & $\begin{array}{r}-0.2091 \\
(0.980)\end{array}$ & $\begin{array}{c}-5.6733 \\
(0.305)\end{array}$ & $\begin{array}{c}-5.2589 \\
(0.339)\end{array}$ & $\begin{array}{r}-3.5732 \\
(0.507)\end{array}$ & $\begin{array}{l}-5.1209 \\
(0.349)\end{array}$ \\
\hline$\Delta \mathrm{VIX} \times$ Illiquidity & $\begin{array}{c}12.6808 \\
(0.761)\end{array}$ & $\begin{array}{c}12.9639 \\
(0.757)\end{array}$ & $\begin{array}{c}-31.9403 \\
(0.201)\end{array}$ & $\begin{array}{c}23.0048 \\
(0.590)\end{array}$ & $\begin{array}{c}20.0424 \\
(0.603)\end{array}$ & $\begin{array}{c}217.1118^{* \star *} \\
(0.000)\end{array}$ & $\begin{array}{c}12.1788 \\
(0.771)\end{array}$ \\
\hline Opacity & $\begin{array}{l}0.0000 \\
(0.948)\end{array}$ & $\begin{array}{l}0.0011 \\
(0.252)\end{array}$ & $\begin{array}{l}0.0002 \\
(0.827)\end{array}$ & $\begin{array}{l}0.0004 \\
(0.718)\end{array}$ & & $\begin{array}{c}0.0027^{* *} \\
(0.039)\end{array}$ & $\begin{array}{l}-0.0002 \\
(0.913)\end{array}$ \\
\hline$\Delta \mathrm{VIX} \times$ Opacity & $\begin{array}{l}-0.0004 \\
(0.216)\end{array}$ & $\begin{array}{l}-0.0010 \\
(0.447)\end{array}$ & $\begin{array}{c}-0.0077^{*} \\
(0.052)\end{array}$ & $\begin{array}{c}-0.0176^{* *} \\
(0.017)\end{array}$ & $\begin{array}{c}-0.0774^{\star * *} \\
(0.000)\end{array}$ & $\begin{array}{c}-0.0164^{* * *} \\
(0.000)\end{array}$ & $\begin{array}{l}0.0057 \\
(0.505)\end{array}$ \\
\hline Observations & 15,194 & 16,024 & 14,782 & 14,780 & 16,128 & 12,293 & 16,128 \\
\hline Number of countries & 23 & 24 & 22 & 22 & 24 & 24 & 24 \\
\hline
\end{tabular}




\section{Table 9 - Granger Causality between Opacity and Volatility}

Granger causality test using a panel VAR(3) of opacity (measured by Corrup - Transparency International's Country Transparency index) and measured market volatility with annual data. Volatility is the standard deviation of equity (MSCI) or bond (EMBIG) daily returns over the period of one year. Corrup is measured annually. The VAR is estimated by OLS

using country and year fixed effects. Reported below are the value of the $\chi^{2}$ statistic and corresponding $p$-value for the joint hypothesis that all the coefficients of lagged volatility in the opacity equation are jointly zero. Non rejection signifies we cannot reject the hypothesis that volatility does not Granger-cause opacity.

\begin{tabular}{lcc}
\hline & $\chi^{2}(3)$ & $p$-value \\
\hline MSCI & 4.55 & 0.2083 \\
EMBIG & 5.05 & 0.1685 \\
\hline
\end{tabular}

